\title{
Associations of ultrasound-based inflammation patterns with peripheral innate lymphoid cell populations, serum cytokine/chemokines, and treatment response to methotrexate in rheumatoid arthritis and spondyloarthritis
}

\section{Manami Kato}

Chiba University Graduate School of Medicine School of Medicine: Chiba Daigaku Daigakuin Igaku Kenkyuin Igakubu

Kei Ikeda ( $\nabla$ K.lkeda@faculty.chiba-u.jp )

Chiba University Hospital https://orcid.org/0000-0003-0574-9611

\section{Takahiro Sugiyama}

Chiba University Graduate School of Medicine School of Medicine: Chiba Daigaku Daigakuin Igaku Kenkyuin Igakubu

\section{Shigeru Tanaka}

Chiba University Graduate School of Medicine School of Medicine: Chiba Daigaku Daigakuin Igaku Kenkyuin Igakubu

\section{Kazuma lida}

Chiba University Graduate School of Medicine School of Medicine: Chiba Daigaku Daigakuin Igaku Kenkyuin Igakubu

\section{Kensuke Suga}

Chiba University Graduate School of Medicine School of Medicine: Chiba Daigaku Daigakuin Igaku Kenkyuin Igakubu

\section{Nozomi Nishimura}

Chiba University Graduate School of Medicine School of Medicine: Chiba Daigaku Daigakuin Igaku Kenkyuin Igakubu

\section{Norihiro Mimura}

Chiba University Graduate School of Medicine School of Medicine: Chiba Daigaku Daigakuin Igaku Kenkyuin Igakubu

\section{Tadamichi Kasuya}

Chiba University Graduate School of Medicine School of Medicine: Chiba Daigaku Daigakuin Igaku Kenkyuin Igakubu

Takashi Kumagai 
Chiba University Graduate School of Medicine School of Medicine: Chiba Daigaku Daigakuin Igaku Kenkyuin Igakubu

\section{Hiroki Furuya}

Chiba University Graduate School of Medicine School of Medicine: Chiba Daigaku Daigakuin Igaku Kenkyuin Igakubu

\section{Taro Iwamoto}

Chiba University Graduate School of Medicine School of Medicine: Chiba Daigaku Daigakuin Igaku Kenkyuin Igakubu

\section{Arifumi Iwata}

Chiba University Graduate School of Medicine School of Medicine: Chiba Daigaku Daigakuin Igaku Kenkyuin Igakubu

\section{Shunsuke Furuta}

Chiba University Graduate School of Medicine School of Medicine: Chiba Daigaku Daigakuin Igaku Kenkyuin Igakubu

\section{Akira Suto}

Chiba University Graduate School of Medicine School of Medicine: Chiba Daigaku Daigakuin Igaku Kenkyuin Igakubu

\section{Kotaro Suzuki}

Chiba University Graduate School of Medicine School of Medicine: Chiba Daigaku Daigakuin Igaku Kenkyuin Igakubu

\section{Eiryo Kawakami}

Chiba University Graduate School of Medicine School of Medicine: Chiba Daigaku Daigakuin Igaku Kenkyuin Igakubu

\section{Hiroshi Nakajima}

Chiba University Graduate School of Medicine School of Medicine: Chiba Daigaku Daigakuin Igaku Kenkyuin Igakubu

\section{Research article}

Keywords: Rheumatoid arthritis, Spondyloarthritis, Ultrasound, Innate lymphoid cell, Cytokine, Chemokine, Methotrexate

Posted Date: November 12th, 2020

DOI: https://doi.org/10.21203/rs.3.rs-105953/v1

License: (c) (1) This work is licensed under a Creative Commons Attribution 4.0 International License. Read Full License 
Version of Record: A version of this preprint was published at PLOS ONE on May 21st, 2021. See the published version at https://doi.org/10.1371/journal.pone.0252116. 


\section{Abstract}

Background: We aimed to clarify the associations of musculoskeletal inflammation patterns with peripheral blood innate lymphoid cell (ILC) populations, serum cytokine/chemokines, and treatment response to methotrexate in patients with rheumatoid arthritis (RA) and spondyloarthritis (SpA).

Methods: We enrolled patients with either RA or SpA who had peripheral symptoms and performed comprehensive ultrasound to evaluate power Doppler signals for synovitis (52 joint regions), tenosynovitis (20 tendons), and enthesitis (44 sites). We performed clustering analysis using unsupervised random forest based on the multi-axis ultrasound information and classified the patients into groups. We identified and counted ILC1-3 populations in the peripheral blood by flow cytometry and also measured the serum levels of 20 cytokine/chemokines. We also determined the American College of Rheumatology 20\% improvement (ACR20) response at 3 months in 38 patients who initiated treatment with methotrexate after baseline assessment.

Results: We enrolled a total of 100 patients with RA $(n=66)$ or SpA $(n=34)$. Synovitis was more prevalent and severer in RA than in SpA, whereas tenosynovitis and enthesitis were comparable between RA and $\mathrm{SpA}$. Patients were classified into two groups which represented synovitis-dominant and synovitisnondominant inflammation patterns, respectively. While peripheral ILC counts were not significantly different between RA and SpA, they were significantly higher in the synovitis-nondominant group than in the synovitis-dominant group (ILC1-3 p =0.0007, $p=0.0061, p=0.0002$, respectively). On the other hand, clustering of patients based on serum cytokine/chemokines did not clearly correspond either to clinical diagnoses or to synovitis-dominant/nondominant patterns. The synovitis-nondominant pattern was the factor that predicted no clinical response to methotrexate most significantly $(p=0.0065)$.

Conclusions: Ultrasound-detected musculoskeletal inflammation is clustered into synovitis-dominant and nondominant patterns. These patterns are associated with peripheral ILC counts and could predict treatment response to methotrexate. These data suggest that ultrasound-based inflammation patterns can be utilized to establish more individualized treatment for both RA and SpA.

Trial registration: The study has been registered in UMIN Clinical Trial Registry (UMIN ID: 000033797, date of registration: $18^{\text {th }}$ of August, 2018).

\section{Background}

Rheumatoid arthritis (RA) and spondyloarthritis (SpA) are the most archetypal entities of inflammatory arthritis. The clinical feature of RA has long been characterized by arthritis, which is the clinical manifestation of synovitis [1], while tenosynovitis has also been shown to be an important pathologic feature of RA that significantly associates with disease and structural progression [2,3]. On the other hand, musculoskeletal manifestations of SpA such as psoriatic arthritis (PSA) and ankylosing spondylitis (AS) are more heterogenous than those of RA, which encompass arthritis, enthesitis, dactylitis, and axial disease [4-6]. Among these, however, enthesitis has been considered the primary site of inflammation, 
which causes synovitis, tenosynovitis, and soft-tissue inflammation, resulting in a variety of clinical manifestations $[7,8]$. It is clinically important to distinguish between these types of musculoskeletal manifestations in SpA because treatment response to medication such as methotrexate (MTX) can be different between the arthritis-dominant disease and the others [9-12]. These data also suggest that the type of musculoskeletal manifestations represents underlying cellular/molecular pathways in SpA, while whether the same concept applies to RA remains unknown.

Imaging modalities such as ultrasound and magnetic resonance imaging (MRI) have played significant roles in understanding the pathophysiology of musculoskeletal inflammation in RA and SpA [13-15]. Importantly, ultrasound and MRI have demonstrated better accuracy in detecting and locating the inflammation as compared with physical examination [13,16-18]. However, the different types of musculoskeletal inflammation have not been thoroughly assessed using these modern imaging techniques for both RA and SpA in a uniform study setting. Therefore, neither clustering of these patients based on comprehensive imaging data nor analyses of associations between such clusters and cellular/molecular biomarkers have been reported yet.

Innate lymphoid cells (ILCs) are the effector cells of innate immune system which are distinct from conventional lymphocytes and involved in protection against pathogens, tissue remodeling, and maintenance of homeostasis [19]. Three ILC subsets, Group 1-3 ILC (ILC1-3), have been identified based on the key transcription factors and cytokine production that resemble helper T cell counterparts [20]. The numbers of ILC1 and ILC3 have been reported to be increased in the peripheral blood, synovial fluid, and lymph node in patients with RA and juvenile idiopathic arthritis (JIA) [21, 22], whereas the number of peripheral ILC2 was decreased [23]. On the other hand, ILC3 has been shown to be present in the healthy entheses and perientheseal bone and expand in the peripheral blood, gut, synovial fluid, or bone marrow in SpA patients and produce key inflammatory cytokines related to SpA [24-29]. Although these reports indicate that ILCs are involved in the pathophysiology of RA and SpA, the associations between ILCs and the patterns of musculoskeletal inflammation are unknown. Similarly, while a number of studies have compared serum cytokine/chemokines between RA, PsA, and controls [30], their associations with musculoskeletal inflammation patterns are poorly understood.

We hypothesized that the patterns of musculoskeletal inflammation determined by comprehensive ultrasound assessment better represent the underlying cellular and molecular pathways and better predict treatment response than do clinical manifestations. We also hypothesized that this association between local inflammation patterns and cellular/molecular pathways is present not only in SpA but also in RA. On the basis of these hypotheses, we aimed in this study to determine the associations of ultrasoundbased inflammation patterns with peripheral blood ILC populations, serum cytokine/chemokines, and treatment response to MTX in patients with RA and SpA.

\section{Methods}

\section{Patients}


We enrolled consecutive patients with either RA or SpA including PsA who had peripheral symptoms on the visit at our outpatient clinic between August 2018 and February 2020. Patients needed to be 18 years or older, fulfill either 2010 American College of Rheumatology (ACR)/ European League Against Rheumatism (EULAR) RA Classification Criteria [1], Classification Criteria for Psoriatic Arthritis (CASPAR) for PsA [4], or Assessment of SpondyloArthritis international Society (ASAS) Criteria for axial or peripheral SpA $[5,6]$, have any peripheral musculoskeletal symptom (i.e. pain, swelling, and/or stiffness in the joint, enthesis, finger, and/or toe), and have disease duration of 10 years or less to be included in this study. Patients who had a concomitant systemic autoimmune/inflammatory disease other than Sjogren syndrome were excluded.

\section{Clinical Assessment}

Patients underwent thorough history taking, chart reviewing, and physical assessment. Specific assessment for RA and SpA included full swollen/tender joint counts (66/68 joints) [31], Spondyloarthritis Research Consortium of Canada (SPARCC) Enthesitis Index [32], dactylitis count (020), patient's pain Visual Analogue Scale (VAS), patient's global assessment VAS, physician's global assessment VAS, and Health Assessment Questionnaire-Disability Index (HAQ-DI). Peripheral white blood cell counts and serum levels of C-reactive protein were obtained on the same day of clinical assessment, whereas information on anti-citrullinated protein antibody (ACPA)/rheumatoid-factor (RF) positivity was collected by chart reviewing. We also collected information on medications patients were receiving for RA or SpA at the time of study assessment.

\section{Ultrasound Examination}

We performed ultrasound assessment for synovitis, tenosynovitis, and enthesitis on the same day of clinical assessment using either a HI VISION Avius or a HI VISION Ascendus (Hitachi Medical Corporation, Tokyo, Japan) depending on availability. For synovitis, we scanned 26 joint sites bilaterally: 1 st interphalangeal (IP) joint, 2nd -5th proximal interphalangeal (PIP) joints, 1st -5th metacarpophalangeal (MCP) joints, radiocarpal joint, midcarpal joint, distal radioulnar joint, humeroradial joint, humeroulnar joint, olecranon fossa, suprapatellar pouch, medial aspect of knee, lateral aspect of knee, tibiotalar joint, talonavicular joint, and 1st -5th metatarsophalangeal (MTP) joints. We excluded distal interphalangeal (DIP) joints, in which discriminating between synovial and entheseal power Doppler (PD) signals is particularly difficult. We also excluded shoulder, where synovitis and tenosynovitis are indistinguishable and degenerative lesions are prevalent. We scored synovial PD signals in each joint region semiquantitatively $(0-3)$ (synovitis score) with a previously validated method $[13,18,33]$.

For tenosynovitis, we scanned 10 tendons bilaterally: flexor digitorum tendons of 1 st -5 th fingers, 2nd, 4th, and 6th compartments of wrist extensor tendons, tibialis posterior, and peroneal tendons. We scored tenosynovial PD signals in each tendon region semiquantitatively $(0-3)$ (tenosynovitis score) with a previously validated method $[13,34]$.

For enthesitis, we scanned 12 entheseal sites bilaterally: extensor digitorum insertions into 1st -5th middle phalanx, lateral epicondyle, medial epicondyle, triceps insertion at olecranon, quadriceps insertion 
at patella, patellar tendon insertions at patella and tibia, and Achilles tendon insertion. We also scanned the extensor digitorum tendons at 1st -5th metacarpal heads and 1st -5th A1 pulleys, which are considered "functional entheses", where inflammation equivalent to enthesitis occurs in PsA/SpA [7, 35]. We scored entheseal PD signals in each tendon region semiquantitatively (0-3) (enthesitis score) based on sonographer's subjective assessment ( 0 , none; 1 , mild signals; 2 , moderate signals; 3 , severe signals).

We calculated total synovitis/tenosynovitis/enthesitis scores by summing up all synovitis/tenosynovitis/enthesitis scores in the patient.

\section{ILC counts}

On the same day of clinical and ultrasound assessment, we obtained fresh whole blood, isolated peripheral blood mononuclear cells (PBMCs) by Ficoll-Paque Premium (GE Healthcare, Chicago, IL, USA), and froze them in CELLBANKER 2 freezing medium (Nippon Zenyaku Kogyo, Fukushima, Japan) at $80^{\circ} \mathrm{C}$. We analyzed the samples by flow cytometry using the following antibodies for surface staining: FITC-conjugated anti-CD3 (UCHT1), anti-CD14 (HCD14), anti-CD19 (HIB19), anti-CD11c (3.9), anti-FceRla (AER-37 [CRA-1]), anti-CD94 (DX22), anti-CD123 (6H6), anti-CD34 (581), anti-CD16 (3G8), BV510conjugated anti-CD45 (HI30), BV421-conjugated anti-CD127 (A019D5), PE-Cy7-conjugated anti-CD117 (ckit) (104D2), Alexa Fluor 647-conjugated anti-CRTH2 (BM16), and APC-Cy7-conjugated anti-CD56 (HCD56).

Data were acquired on FACS CANTO II (BD Biosciences, San Jose, CA, USA) and analyzed with FlowJo software (Tree Star, Ashland, OR, USA). Total ILC, ILC1, ILC2, and ILC3 were identified using gating methods previously reported [36] (Fig. 1). In summary, after gating on live lymphoid cells, singlets, and $\mathrm{CD}_{4} 5^{+}$cells, we identified ILCs as lineage markers ${ }^{-} \mathrm{CD} 127^{+}$cells.

We confirmed no significant differences in any populations tested before and after freezing (data not shown).

\section{Serum Cytokine/chemokines}

There were statistically significant differences between RA and SpA in the serum levels of $\beta$-defensin 2 , IFN- $y$, IL-22, IL-23, IL-17F, GM-CSF, CCL20/MIP3a, IL-15, IL-1 $\beta$, IL-17A, and IL-6 (Table 2). However, hierarchical clustering demonstrated that the cytokine/chemokine profile as a whole does not clearly discriminate between RA and SpA (Fig. 6). 
Table 2

Differences in serum biomarkers between rheumatoid arthritis and spondyloarthritis

\begin{tabular}{|c|c|c|c|}
\hline & $\begin{array}{l}\text { Rheumatoid arthritis } \\
(n=65)\end{array}$ & $\begin{array}{l}\text { Spondyloarthritis } \\
(n=34)\end{array}$ & p-value \\
\hline$\beta$-defensin2, ng/ml & $0.209(0.094-0.397)$ & $1.77(0.595-5.06)$ & $<0.0001$ \\
\hline Calprotectin, $\mu \mathrm{g} / \mathrm{ml}$ & $2.94(2.35-3.75)$ & $2.69(2.22-3.75)$ & 0.5012 \\
\hline CCL20/MIP3a, pg/ml & $31.4(15.9-64.8)$ & $13.3(1.27-29.8)$ & 0.0012 \\
\hline C-reactive protein, $\mathrm{mg} / \mathrm{dl}$ & $0.270(0.075-1.92)$ & $0.340(0.09-1.47)$ & 0.8968 \\
\hline GM-CSF, pg/ml & $12.4(0.00-96.5)$ & $0.00(0.00-7.38)$ & 0.0005 \\
\hline $\mathrm{IFN}-\mathrm{y}, \mathrm{pg} / \mathrm{ml}$ & $4.78(1.50-18.5)$ & $1.21(0.00-3.90)$ & $<0.0001$ \\
\hline $\mathrm{IL}-1 \beta, \mathrm{pg} / \mathrm{ml}$ & $1.51(0.00-4.79)$ & $0.138(0.00-1.08)$ & 0.0038 \\
\hline $\mathrm{IL}-6, \mathrm{pg} / \mathrm{ml}$ & $3.70(0.00-20.3)$ & $0.00(0.00-4.38)$ & 0.0426 \\
\hline IL-8, pg/ml & $13.2(6.82-41.5)$ & $16.5(7.92-60.2)$ & 0.5141 \\
\hline IL-9, pg/ml & $0.00(0.00-17.4)$ & $0.00(0.00-0.464)$ & 0.0762 \\
\hline IL-10, pg/ml & $0.118(0.00-1.94)$ & $0.00(0.00-0.87)$ & 0.3849 \\
\hline IL-12p70, pg/ml & $2.89(1.21-12.1)$ & $2.70(1.24-3.83)$ & 0.1687 \\
\hline IL-15, pg/ml & $1.96(0.00-10.4)$ & $0.00(0.00-2.46)$ & 0.0026 \\
\hline IL-17A, pg/ml & $1.07(0.00-4.58)$ & $0.0231(0.00-2.06)$ & 0.0324 \\
\hline IL-17F, pg/ml & $3.93(0.00-133.3)$ & $0.00(0.00-1.87)$ & 0.0004 \\
\hline IL-21, pg/ml & $10.8(5.15-27.0)$ & $12.4(6.99-16.9)$ & 0.7957 \\
\hline IL-22, ng/ml & $0.00(0.00-2.51)$ & $0.00(0.00-0.00)$ & $<0.0001$ \\
\hline IL-23, ng/ml & $0.480(0.00-7.67)$ & $0.00(0.00-0.012)$ & $<0.0001$ \\
\hline Lipocalin-2/NGAL, $\mu \mathrm{g} / \mathrm{ml}$ & $0.365(0.204-0.658)$ & $0.438(0.321-0.683)$ & 0.0527 \\
\hline TNF-a, pg/ml & $11.0(7.39-20.9)$ & $12.0(6.54-25.8)$ & 0.8702 \\
\hline
\end{tabular}

There were also statistically significant differences between Group 1 and Group 2 in the serum levels of C-reactive protein, calprotectin, $\beta$-defensin 2, and CCL20/MIP3a (Table 3). Interestingly, $\beta$-defensin 2 was the only cytokine/chemokine that was significantly different both between RA and SpA and between Group 1 and Group 2. Nevertheless, the cytokine/chemokine clustering did not clearly discriminate between Group 1 and Group 2, either (Fig. 6). 
Table 3

Differences in serum biomarkers between groups based on ultrasound

\begin{tabular}{|c|c|c|c|}
\hline & $\begin{array}{l}\text { Group } 1 \\
\text { (Synovitis-dominant) } \\
(n=37)\end{array}$ & $\begin{array}{l}\text { Group } 2 \\
\text { (Synovitis-nondominant) } \\
(n=62)\end{array}$ & p-value \\
\hline$\beta$-defensin2, ng/ml & $0.232(0.095-0.478)$ & $0.394(0.139-1.75)$ & 0.0256 \\
\hline Calprotectin, $\mu \mathrm{g} / \mathrm{ml}$ & $3.51(2.49-4.06)$ & $2.62(1.93-3.26)$ & 0.0020 \\
\hline CCL20/MIP3a, pg/ml & $34.4(17.2-77.5)$ & $21.2(6.02-40.5)$ & 0.0282 \\
\hline C-reactive protein, $\mathrm{mg} / \mathrm{dl}$ & $0.970(0.365-3.26)$ & $0.135(0.050-0.733)$ & $<0.0001$ \\
\hline GM-CSF, pg/ml & $0.00(0.00-90.2)$ & $0.00(0.00-37.0)$ & 0.6965 \\
\hline IFN-y, pg/ml & $2.79(1.29-16.0)$ & $3.66(0.440-7.80)$ & 0.7428 \\
\hline $\mathrm{IL}-1 \beta, \mathrm{pg} / \mathrm{ml}$ & $0.637(0.00-3.10)$ & $0.483(0.00-2.78)$ & 0.7344 \\
\hline IL-6, pg/ml & $4.62(0.00-22.0)$ & $0.00(0.00-13.6)$ & 0.1413 \\
\hline IL-8, pg/ml & $15.6(8.47-31.0)$ & $13.3(6.41-54.2)$ & 0.9250 \\
\hline IL-9, pg/ml & $0.00(0.00-19.7)$ & $0.00(0.00-12.6)$ & 0.6623 \\
\hline $\mathrm{IL}-10, \mathrm{pg} / \mathrm{ml}$ & $0.536(0.00-1.94)$ & $0.00(0.00-0.87)$ & 0.2274 \\
\hline IL-12p70, pg/ml & $2.44(0.986-13.3)$ & $2.70(1.53-5.30)$ & 0.7686 \\
\hline $\mathrm{IL}-15, \mathrm{pg} / \mathrm{ml}$ & $1.97(0.00-8.90)$ & $0.054(0.00-5.96)$ & 0.3852 \\
\hline IL-17A, pg/ml & $0.38(0.00-2.33)$ & $1.19(0.00-4.13)$ & 0.4876 \\
\hline IL-17F, pg/ml & $0.00(0.00-123)$ & $0.00(0.00-35.5)$ & 0.6722 \\
\hline $\mathrm{IL}-21, \mathrm{pg} / \mathrm{ml}$ & $8.70(5.41-26.9)$ & $13.1(6.99-21.2)$ & 0.5823 \\
\hline $\mathrm{IL}-22, \mathrm{ng} / \mathrm{ml}$ & $0.00(0.00-2.08)$ & $0.00(0.00-0.477)$ & 0.6352 \\
\hline IL-23, ng/ml & $0.00(0.00-5.27)$ & $0.00(0.00-2.23)$ & 0.5646 \\
\hline Lipocalin-2/NGAL, $\mu \mathrm{g} / \mathrm{ml}$ & $0.296(0.205-0.619)$ & $0.424(0.253-0.729)$ & 0.1702 \\
\hline TNF-a, pg/ml & $11.7(6.90-26.0)$ & $11.3(7.43-22.3)$ & 0.8795 \\
\hline
\end{tabular}

We also analyzed correlations between serum cytokine/chemokines and peripheral ILC numbers. Only a few combinations showed a statistically significant correlation and the correlations were all weak (Table 4). 
Table 4

Correlations between serum biomarkers and numbers of peripheral innate lymphoid cell populations

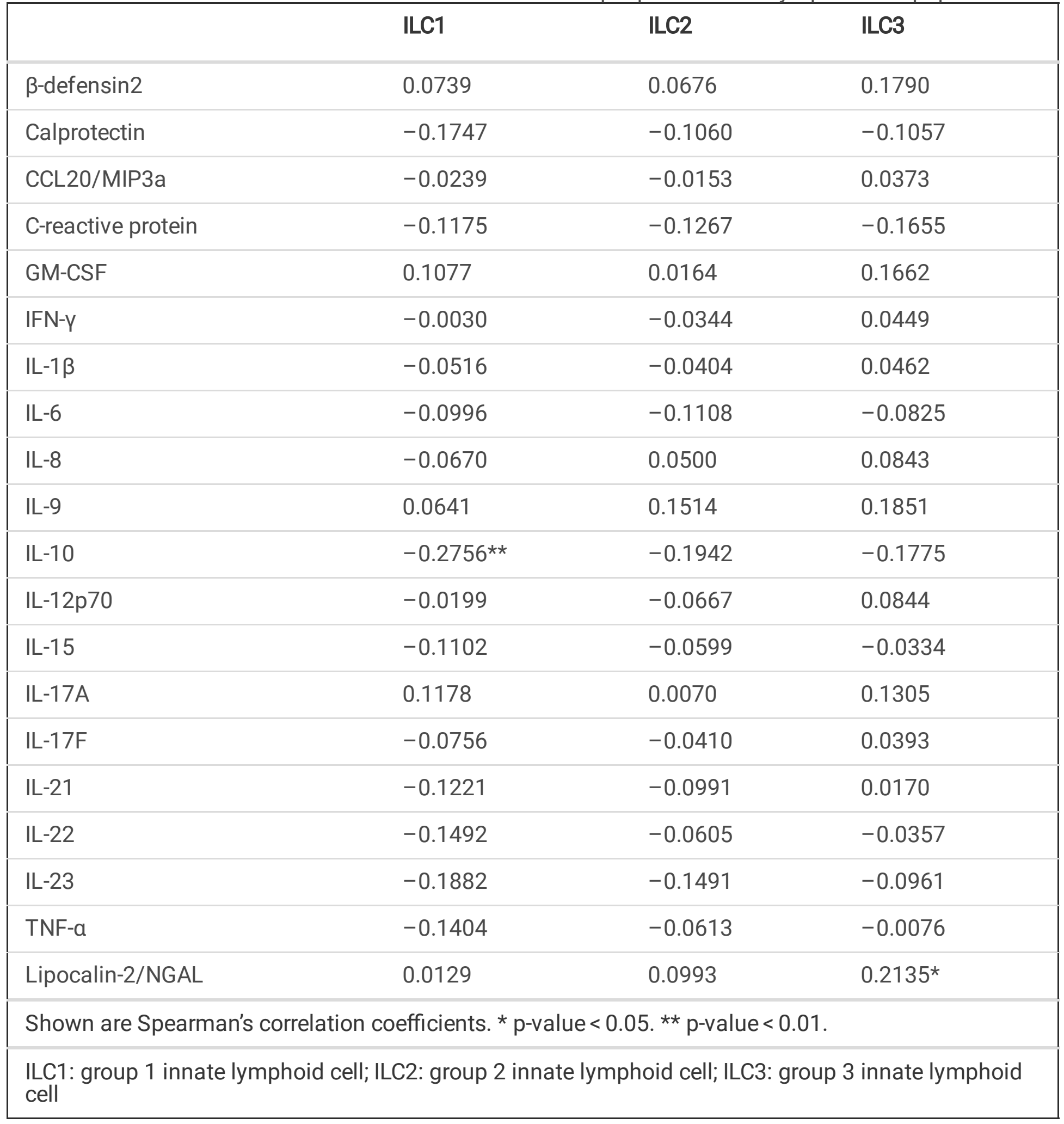

\section{Treatment Response}

Thirty-eight patients (RA 26, SpA 12) initiated MTX-monotherapy $(n=37)$ or added MTX to salazosulfapyridine $(n=1)$ within 12 weeks of study assessment. All of these patients stayed on the 
same regimen for 12 weeks or longer and the median (IQR) maximum weekly dose of MTX during within months was 10 (10-12) mg. At 12 weeks, 26 (68.4\%) achieved ACR20 response.

Table 5 summarizes the differences in baseline factors between patients who achieved ACR20 response to MTX and those who did not. The most significant factor that predicted treatment response was the Group 1/2 inflammation pattern. In fact, none in Group 2 achieved ACR20 to MTX at 12 weeks (Fig. 4I). The other factors significantly predictive of no treatment response to MTX were younger age, psoriatic skin lesion, diagnosis of SpA, inflammatory back pain, and lower swollen joint count (Table 5). 
Table 5

Differences in baseline variables between patients who responded to methotrexate and those who did not

\begin{tabular}{|c|c|c|c|}
\hline & $\begin{array}{l}\text { ACR20 } \\
\text { achieved } \\
(n=26)\end{array}$ & $\begin{array}{l}\text { ACR20 } \\
\text { not achieved } \\
(n=12)\end{array}$ & $\begin{array}{l}\mathrm{p}- \\
\text { value }\end{array}$ \\
\hline Diagnosis: rheumatoid arthritis, number (\%) & $21(80.8)$ & $5(41.7)$ & 0.0258 \\
\hline Mean age $\pm S D$, year-old & $61.6 \pm 14.9$ & $50.1 \pm 13.3$ & 0.0252 \\
\hline Female, number (\%) & $15(57.7)$ & $7(58.3)$ & 1.0000 \\
\hline Mean Body Mass Index $\pm \mathrm{SD}, \mathrm{kg} / \mathrm{m}^{2}$ & $23.54 \pm 3.70$ & $23.90 \pm 4.24$ & 0.7998 \\
\hline Mean disease duration $\pm \mathrm{SD}$, month & $11.0 \pm 12.7$ & $14.4 \pm 11.8$ & 0.4216 \\
\hline Median swollen joint count (66 joint) (IQR) & $5(3-16)$ & $2(1-6.75)$ & 0.0300 \\
\hline Median tender joint count (68 joint) (IQR) & $4.5(2.75-8.25)$ & $3(1-6)$ & 0.1144 \\
\hline Median SPARCC Enthesitis Index (0-16) (IQR) & $0(0-0.25)$ & $0.5(0-2)$ & 0.1455 \\
\hline Median dactylitis score (20 finger/toe) (IQR) & $0(0-0)$ & $0(0-1)$ & 0.0512 \\
\hline Median HAQ-DI (IQR) & $\begin{array}{l}0.75(0.25- \\
1.16)\end{array}$ & $0.5625(0.031-1)$ & 0.2485 \\
\hline Median serum C-reactive protein (IQR), mg/dl & $\begin{array}{l}0.63(0.21- \\
3.22)\end{array}$ & $\begin{array}{l}0.265(0.09- \\
3.84)\end{array}$ & 0.7467 \\
\hline Mean Patient's Pain VAS $(0-100) \pm$ SD & $54.7 \pm 27.7$ & $43.2 \pm 25.1$ & 0.2146 \\
\hline Mean Patient's Global VAS $(0-100) \pm$ SD & $56.1 \pm 30.8$ & $50.6 \pm 24.7$ & 0.5588 \\
\hline Mean Physician's Global VAS $(0-100) \pm$ SD & $42.3 \pm 22.7$ & $35.0 \pm 24.2$ & 0.3880 \\
\hline Rheumatoid factor positive, number (\%) & $14(53.9)$ & $4(33.3)$ & 0.3067 \\
\hline $\begin{array}{l}\text { Anti-citrullinated protein antibody positive, number } \\
(\%)\end{array}$ & $13(50.0)$ & $4(33.3)$ & 0.4862 \\
\hline Inflammatory back pain ever present, number (\%) & $0(0.0)$ & $3(25.0)$ & 0.0261 \\
\hline Psoriatic skin lesion ever present, number (\%) & $5(19.2)$ & $7(58.3)$ & 0.0258 \\
\hline Nail lesion present, number (\%) & $4(15.4)$ & $4(33.3)$ & 0.2319 \\
\hline Cluster: Group 1 (synovitis-dominant), number (\%) & $12(46.2)$ & $0.0(0.0)$ & 0.0065 \\
\hline \multicolumn{4}{|c|}{$\begin{array}{l}\text { SD: standard deviation; IQR: interquartile range; SPARCC: Spondyloarthritis Research Consortium of } \\
\text { Canada; HAQ-DI: Health Assessment Questionnaire-Damage Index; VAS: visual analogue scale; } \\
\text { NSAID: non-steroidal anti-inflammatory drug }\end{array}$} \\
\hline
\end{tabular}




\section{Statistics}

Normally distributed continuous data were summarized with mean and standard deviation (SD) and were compared using Welch's T test. Non-normally distributed data were summarized with median and interquartile range (IQR) and were analyzed using Brunner-Munzel test and Spearman's correlation coefficient. Categorical data were presented with numbers and percentages and compared using Chi's square or Fisher's exact test.

Hierarchical clustering was performed to analyze the similarity among patients based on serum cytokine/chemokine levels. An unsupervised random forest dissimilarity measure [40, 41] was used to evaluate the similarity among patients based on ultrasound scores. The random forest dissimilarity was used as input for Uniform Manifold Approximation and Projection (UMAP) [42], which provides a visual representation of the positional relationship among a set of patients. Subsequently, Partitioning Around Medoids (PAM) clustering [43] was applied on the two scaling coordinates of UMAP.

Welch's t-test, Chi's square test, Fisher's exact test, Spearman's correlation coefficient, and hierarchical clustering were performed by using JMP Pro 13.2 (SAS Institute Inc., Cary, NC, USA). Brunner-Munzel test was performed by using $\mathrm{R}$ lawstat package. Random forest, UMAP, and PAM clustering were performed by using python scikit-learn package, python umap package, and R cluster package, respectively. Twosided $\mathrm{p}$-values less than 0.05 were considered statistically significant.

\section{Results}

\section{Patients}

A total of 100 patients were enrolled (RA 66, SpA 34 [PsA 29, non-PsA 5]). Table 1 summarizes the patients' and disease characteristics and treatment. Among SpA patients, 6 and 1 patients fulfilled the ASAS classification of radiographic and non-radiographic axial SpA, respectively [5]; 4 had or had previously had inflammatory back pain but were not classified as axial SpA. All PsA patients had or had previously had psoriatic skin lesions. Two non-PsA SpA patients had ulcerative colitis and one PsA patient had uveitis. One RA patient had Sjogren's syndrome and three had local autoimmune diseases (Type 1 diabetes mellitus 2 [RA 1, PsA 1]; Basedow's disease 1 [PsA]). Patient's and Physician's Global VAS indicated that the study subjects largely represented patients with mild to moderate arthritic disease activity. 
Table 1

Patient and disease characteristics

\begin{tabular}{|c|c|c|c|}
\hline & $\begin{array}{l}\text { Total } \\
(n=100)\end{array}$ & $\begin{array}{l}\text { Rheumatoid } \\
\text { arthritis } \\
(n=66)\end{array}$ & $\begin{array}{l}\text { Spondyloarthritis } \\
(n=34)\end{array}$ \\
\hline Mean age $\pm S D$, year-old & $57.8 \pm 14.6$ & $61.5 \pm 14.9$ & $50.7 \pm 11.2$ \\
\hline Female, number (\%) & $60(60.0)$ & $50(75.8)$ & $10(29.4)$ \\
\hline Mean Body Mass Index $\pm S D, \mathrm{~kg} / \mathrm{m}^{2}$ & $23.5 \pm 4.01$ & $22.4 \pm 3.20$ & $25.8 \pm 4.49$ \\
\hline Mean disease duration $\pm \mathrm{SD}$, month & $32.1 \pm 36.1$ & $28.5 \pm 34.4$ & $39.1 \pm 38.7$ \\
\hline Median swollen joint count (66 joint) (IQR) & $3(1-7)$ & $5(2-10.25)$ & $1(0-2.25)$ \\
\hline Median tender joint count (68 joint) (IQR) & $3(1-5.75)$ & $3(1-7)$ & $2(1-5)$ \\
\hline $\begin{array}{l}\text { Median SPARCC Enthesitis Index (0-16) } \\
\text { (IQR) }\end{array}$ & $0(0-0.75)$ & $0(0-0)$ & $1(0-2)$ \\
\hline $\begin{array}{l}\text { Median dactylitis score (20 finger/toe) } \\
\text { (IQR) }\end{array}$ & $0(0-0)$ & $0(0-0)$ & $0(0-0)$ \\
\hline Median HAQ-DI (IQR) & $0.5(0.125-1)$ & $\begin{array}{l}0.6875(0.125- \\
1.125)\end{array}$ & $0.25(0-0.906)$ \\
\hline $\begin{array}{l}\text { Median serum C-reactive protein (IQR), } \\
\mathrm{mg} / \mathrm{dl}\end{array}$ & $\begin{array}{l}0.30(0.08- \\
1.76)\end{array}$ & $0.27(0.07-1.92)$ & $0.34(0.09-1.47)$ \\
\hline Mean Patient's Pain VAS $(0-100) \pm$ SD & $43.2 \pm 27.2$ & $46.1 \pm 26.2$ & $37.6 \pm 28.8$ \\
\hline Mean Patient's Global VAS $(0-100) \pm$ SD & $49.4 \pm 29.6$ & $52.6 \pm 28.9$ & $43.1 \pm 30.3$ \\
\hline Mean Physician's Global VAS $(0-100) \pm$ SD & $35.8 \pm 24.7$ & $41.9 \pm 23.8$ & $24.0 \pm 22.2$ \\
\hline Rheumatoid factor positive, number (\%) & $52(52.0)$ & $49(74.2)$ & $3(8.8)$ \\
\hline $\begin{array}{l}\text { Anti-citrullinated protein antibody positive, } \\
\text { number (\%) }\end{array}$ & $48(48.0)$ & $48(72.7)$ & $0(0.0)$ \\
\hline $\begin{array}{l}\text { Inflammatory back pain ever present, } \\
\text { number (\%) }\end{array}$ & $11(11.0)$ & $0(0.0)$ & $11(32.4)$ \\
\hline $\begin{array}{l}\text { Psoriatic skin lesion ever present, number } \\
(\%)\end{array}$ & $29(29.0)$ & $0(0.0)$ & $29(85.3)$ \\
\hline Nail lesion ever present, number (\%) & $19(19.0)$ & $0(0.0)$ & $19(55.9)$ \\
\hline No treatment, number (\%) & $23(23.0)$ & $14(21.2)$ & $9(26.5)$ \\
\hline \multicolumn{4}{|c|}{$\begin{array}{l}\text { SD: standard deviation; IQR: interquartile range; SPARCC: Spondyloarthritis Research Consortium of } \\
\text { Canada; HAQ-DI: Health Assessment Questionnaire-Damage Index; VAS: visual analogue scale; } \\
\text { NSAID: non-steroidal anti-inflammatory drug; DMARD: disease-modifying anti-rhuematic drug; } \\
\text { cSDMARD: conventional synthetic DMARD; bDMARD: biological DMARD; tsDMARD: targeted } \\
\text { synthetic DMARD }\end{array}$} \\
\hline
\end{tabular}




\begin{tabular}{|c|c|c|c|}
\hline & $\begin{array}{l}\text { Total } \\
(n=100)\end{array}$ & $\begin{array}{l}\text { Rheumatoid } \\
\text { arthritis } \\
(n=66)\end{array}$ & $\begin{array}{l}\text { Spondyloarthritis } \\
(n=34)\end{array}$ \\
\hline Receiving NSAID, number (\%) & $46(46.0)$ & $33(50.0)$ & $13(38.2)$ \\
\hline Receiving Glucocorticoid, number (\%) & $3(3.0)$ & $2(3.0)$ & $1(3.0)$ \\
\hline Receiving csDMARD, number (\%) & $32(32.0)$ & $23(34.8)$ & $9(26.5)$ \\
\hline Receiving bDMARD, number (\%) & $9(9.0)$ & $6(9.1)$ & $3(8.8)$ \\
\hline Receiving tsDMARD, number (\%) & $5(5.0)$ & $1(1.5)$ & $4(11.8)$ \\
\hline \multicolumn{4}{|c|}{$\begin{array}{l}\text { SD: standard deviation; IQR: interquartile range; SPARCC: Spondyloarthritis Research Consortium of } \\
\text { Canada; HAQ-DI: Health Assessment Questionnaire-Damage Index; VAS: visual analogue scale; } \\
\text { NSAID: non-steroidal anti-inflammatory drug; DMARD: disease-modifying anti-rhuematic drug; } \\
\text { cSDMARD: conventional synthetic DMARD; bDMARD: biological DMARD; tsDMARD: targeted } \\
\text { synthetic DMARD }\end{array}$} \\
\hline
\end{tabular}

\section{Ultrasound And Clustering}

Figure 2 summarizes the ultrasound results. As expected, active synovitis was more prevalent in RA than in SpA in the vast majority of joints assessed, with MCP and wrist joints being the most commonly inflamed joints (Fig. 2A). On the other hand, the prevalence of active tenosynovitis was similar between RA and SpA overall although it was higher in 4th and 6th compartments of wrist extensor tendons in RA (Fig. 2B). Unexpectedly, the prevalence of active enthesitis was not higher in SpA overall and it was even higher in the functional entheses of extensor digitorum in RA (Fig. 2C). Consistently, total synovitis score was significantly higher in RA than in SpA, while total tenosynovitis score and total enthesitis score were comparable between RA and SpA (Fig. 3).

Next, we assessed the similarity among these patients based on these ultrasound scores using unsupervised random forest and UMAP as described in the Patients and Methods section. As shown in Fig. 4A, patients are clustered into two groups (Group 1, $n=38$; Group 2, $n=62$ ). Interestingly, this ultrasound-based grouping did not clearly correspond to patients' diagnosis or ACPA positivity although the majority of PsA patients belonged to Group 2 (Fig. 4B, 4C). On the other hand, patients with a high total synovitis score clustered into Group 1, whereas those with a low synovitis score clustered into Group 2 (Fig. 4D). There was a similar but weaker association of this grouping with the total tenosynovitis score in the same direction (Fig. 4E), while there was an also weak but the opposite association of the grouping with the total enthesitis score (Fig. 4F). We did not find any significant associations between this grouping and the location of inflamed joint regions (e.g. small vs. large joints, fingers/toes vs. others, upper vs. lower extremities) (data not shown). These data demonstrate that Group 1 represents patients with a "synovitis-dominant" inflammation pattern, whereas Group 2 represents those with a "synovitisnondominant" inflammation pattern. 
ILC

There were no significant differences between RA and SpA in either white blood cell count, lymphocyte count, or neutrophil count (data not shown). As shown in Fig. 5A, median numbers of ILCs were numerically larger in SpA than in RA but the differences were, unexpectedly, not statistically significant.

On the other hand, when mapped on ultrasound-based clustering, the numbers of ILCs, particularly ILC3, seemed to be higher in Group 2 than in Group 1 (Fig. 4G, 4H). In fact, median ILC counts were significantly higher in Group 2 than in Group 1 (Fig. 5B), indicating that peripheral ILC numbers are more closely associated with musculoskeletal inflammation patterns than with clinical diagnoses.

\section{Discussion}

Here, we demonstrate that patients with RA and SpA can be classified into two groups based on the anatomical locations of musculoskeletal inflammation determined by ultrasound examination of peripheral joints, tendons, and entheses. These clusters represented "synovitis-dominant" and "synovitisnondominant" patterns but did not clearly correspond to clinical diagnoses (i.e., RA and SpA). Furthermore, peripheral ILC counts were significantly associated with ultrasound-based inflammation patterns but not with clinical diagnoses. In addition, the synovitis-nondominant pattern was the strongest predictor of no clinical response to MTX.

To our knowledge, this is the first report of comprehensive ultrasound assessment for synovitis, tenosynovitis, and enthesitis in both RA and SpA in the same research setting. The most unexpected finding was that RA patients showed enthesitis as frequently as did SpA patients (Fig. 2). In particular, the inflammation in extensor digitorum at metacarpal head (i.e. functional enthesis), which was reported to distinguish between PsA and RA [44], was identified more frequently in RA than in SpA. Although the seemingly lower disease activity in SpA patients and the possible influence from adjacent synovitis need to be taken into consideration, our data indicate that a significant proportion of RA patients develop enthesitis. Together with the already known notion that the peripheral musculoskeletal inflammation in $\mathrm{SpA}$ is diverse, our data suggest that musculoskeletal inflammation in RA and SpA are considerably heterogenous, consisting of different ratios of synovitis, tenosynovitis, and enthesitis in individual patients.

This study is also the first to classify patients with inflammatory arthritis using a clustering method incorporating multi-axis ultrasound information. The clustering demonstrates that these patients can be divided into two groups depending on the predominance of synovitis over enthesitis (Fig. 4D, 4F). These groups did not clearly coincide with either clinical diagnosis (Fig. 4B), ACPA positivity (Fig. 4C), or rheumatoid factor positivity (data not shown), illustrating again the heterogeneity of musculoskeletal inflammation within the same diagnosis or seropositivity.

Unexpectedly, there were no statistically significant differences in the numbers of any ILC populations in the peripheral blood between RA and SpA (Fig. 5A). Instead, numbers of all ILC populations, particularly 
ILC3 and ILC1, were significantly higher in the synovitis-nondominant group than in the synovitisdominant group (Fig. 5B). While ILCs are characterized by their tissue-resident roles [20], recent studies have suggested that ILC3 migrates from gut to inflammatory sites through peripheral blood in SpA [24, 45]. Our data support the link between the peripheral blood ILC and the local musculoskeletal inflammation not only in SpA but also in RA. Our data also indicate that the numbers of peripheral ILC1-3 closely correlate with each other and their balance does not clearly discriminate between diseases or musculoskeletal inflammation patterns.

In our study, clustering of arthritis patients on the basis of 20 serum cytokine/chemokine levels did not clearly correspond to clinical diagnosis or ultrasound-based clustering (Fig. 6). Among 11 individual cytokine/chemokines that were significantly different between RA and SpA, 10 were more elevated in RA than in SpA (Table 2), probably reflecting the higher inflammatory activity in RA patients than in SpA patients enrolled in this study. These cytokine/chemokines unexpectedly included IL-17A, IL-17F, and IL23 , which are considered to play more significant roles in SpA than in RA [46, 47]. Given that serum levels of these three cytokine/chemokines were not significantly different between synovitis-dominant and synovitis-nondominant groups (Table 3), the reason for this unexpected result might be the higher disease activity in RA and the presence of some synovitis-nondominant RA patients who had high serum levels of these cytokine/chemokines in our study. $\beta$-defensin 2 , the only cytokine/chemokine that was significantly higher in SpA than in RA, was preferentially elevated in PsA. In fact, the seven patients with the highest serum levels of $\beta$-defensin 2, a small cluster shown in Fig. 6 , were all PsA patients. The result confirms the already established role of $\beta$-defensin 2 as a potent serum biomarker of psoriasis $[38,48]$. Collectively, these data indicate that the cytokine/chemokines we measured in this study are generally not reliable biomarkers for the peripheral musculoskeletal inflammation.

In our pilot, small scale analysis, the synovitis-nondominant pattern was more significantly associated with no clinical response to MTX than was SpA diagnosis. This result was expected as it is in line with the notion that MTX is efficacious for arthritis, which is usually a clinical manifestation of synovitis, but not for enthesitis in SpA [9]. However, the evidence related to this theory has actually been conflicting [49, 50]. One possible reason for the inconsistent results may be the limited or varying capability of physical examination to discriminate between arthritis, enthesitis, and dactylitis [15]. To support this, the predictive values of joint counts and enthesitis/dactylitis scores for MTX response in our study were much smaller as compared with the ultrasound-based inflammation pattern (Table 5).

The limitations of this study include the rather small sample size, which limited the reliability and made performing multivariate analysis difficult. Second, the disease activity, especially in SpA, was not high, which might have influenced the results. However, it is technically difficult to match disease activity between two different diseases. Moreover, a fairly wide variety of active lesions were present also in SpA patients, which was sufficient for the distinct inflammation patterns to be illustrated with UMAP.

\section{Conclusions}


Our data demonstrate that patients with RA and SpA can be classified into two groups representing synovitis-dominant and synovitis-nondominant inflammation patterns. Our data also show that these patterns are associated with peripheral blood ILC counts and predictive of clinical response to MTX. These results indicate that imaging-detected patterns of musculoskeletal inflammation reflect underlying molecular/cellular pathophysiology and can be utilized to establish more individualized treatment for both RA and SpA.

\section{Abbreviations}

ACR: American College of Rheumatology; ACR20: American College of Rheumatology $20 \%$ improvement; ACPA: anti-citrullinated protein antibody; AS: ankylosing spondylitis; ASAS: Assessment of SpondyloArthritis international Society; CASPAR: Classification Criteria for Psoriatic Arthritis; DIP: distal interphalangeal; DMARD: disease modifying anti-rheumatic drug; EULAR: European League Against Rheumatism; HAQ-DI: Health Assessment Questionnaire-Disability Index; ILC: innate lymphoid cell; IP: interphalangeal; IQR: interquartile range; JIA: juvenile idiopathic arthritis; MCP: metacarpophalangeal; MRI: magnetic resonance imaging; MTP: metatarsophalangeal; MTX: methotrexate; PBMC: peripheral blood mononuclear cell; PAM: Partitioning Around Medoids; PD: power Doppler; PIP: proximal interphalangeal; PsA: psoriatic arthritis; RA: rheumatoid arthritis; RF: rheumatoid factor; SpA: spondyloarthritis; SD: standard deviation; SPARCC: Spondyloarthritis Research Consortium of Canada; UMAP: Uniform Manifold Approximation and Projection; VAS: Visual Analogue Scale.

\section{Declarations}

\section{Ethics approval and consent to participate}

All study procedures were approved by Chiba University Ethics Committee on August $17^{\text {th }}, 2018$ (approved number: 3121) and performed in accordance with the Declaration of Helsinki. All patients gave written informed consent before receiving any study procedures.

\section{Consent for publication}

Not applicable

\section{Availability of data and materials}

The datasets used and/or analysed during the current study are available from the corresponding author on reasonable request.

\section{Competing interests}

The authors declare that they have no competing interests as regards this work.

\section{Funding}


This work was supported by Grants-in-Aids for Scientific Research from the Ministry of Education, Culture, Sports, Science and Technology (MEXT) (Grant number: 18K08405).

\section{Authors' contributions}

MK, Kel, TI, SF, KoS, and HN substantially contributed to the conception and design of the work. MK, Kel, TS, Kal, KeS, NN, NM, TadK, TakK, ST, SF, and AS substantially contributed to the acquisition of data. MK, $\mathrm{Kel}, \mathrm{ST}, \mathrm{HF}, \mathrm{Al}, \mathrm{SF}$, EK, and HN substantially contributed to the interpretation of data. MK and Kel drafted the manuscript and MK, Kel, ST, HF, Al, SF, EK, and HN substantively revised it.

All authors have approved the submitted version of manuscript and agreed both to be personally accountable for the author's own contributions and to ensure that questions related to the accuracy or integrity of any part of the work, even ones in which the author was not personally involved, are appropriately investigated, resolved, and the resolution documented in the literature.

\section{Acknowledgements}

We thank Ms. Kazumi Nemoto for helping with PBMC isolation and Ms. Chisato Ishii for data acquisition and collection. We also thank all hospital staff members who provided care to the patients.

\section{References}

1. Aletaha D, Neogi T, Silman AJ, Funovits J, Felson DT, Bingham CO, 3rd, Birnbaum NS, Burmester GR, Bykerk VP, Cohen MD, Combe B, Costenbader KH, Dougados M, Emery P, Ferraccioli G, Hazes JM, Hobbs K, Huizinga TW, Kavanaugh A, Kay J, Kvien TK, Laing T, Mease P, Menard HA, Moreland LW, Naden RL, Pincus T, Smolen JS, Stanislawska-Biernat E, Symmons D, Tak PP, Upchurch KS, Vencovsky J, Wolfe F, Hawker G: 2010 Rheumatoid arthritis classification criteria: an American College of Rheumatology/European League Against Rheumatism collaborative initiative. Arthritis Rheum 2010, 62(9):2569-2581.

2. Lillegraven S, Boyesen P, Hammer HB, Ostergaard M, Uhlig T, Sesseng S, Kvien TK, Haavardsholm EA: Tenosynovitis of the extensor carpi ulnaris tendon predicts erosive progression in early rheumatoid arthritis. Ann Rheum Dis 2011, 70(11):2049-2050.

3. van Steenbergen HW, Mangnus L, Reijnierse M, Huizinga TW, van der Helm-van Mil AH: Clinical factors, anticitrullinated peptide antibodies and MRI-detected subclinical inflammation in relation to progression from clinically suspect arthralgia to arthritis. Ann Rheum Dis 2016, 75(10):1824-1830.

4. Taylor W, Gladman D, Helliwell P, Marchesoni A, Mease P, Mielants H: Classification criteria for psoriatic arthritis: development of new criteria from a large international study. Arthritis Rheum 2006, 54(8):2665-2673.

5. Rudwaleit M, van der Heijde D, Landewe R, Listing J, Akkoc N, Brandt J, Braun J, Chou CT, CollantesEstevez E, Dougados M, Huang F, Gu J, Khan MA, Kirazli Y, Maksymowych WP, Mielants H, Sorensen IJ, Ozgocmen S, Roussou E, Valle-Onate R, Weber U, Wei J, Sieper J: The development of Assessment 
of SpondyloArthritis international Society classification criteria for axial spondyloarthritis (part II): validation and final selection. Ann Rheum Dis 2009, 68(6):777-783.

6. Rudwaleit M, van der Heijde D, Landewe R, Akkoc N, Brandt J, Chou CT, Dougados M, Huang F, Gu J, Kirazli Y, Van den Bosch F, Olivieri I, Roussou E, Scarpato S, Sorensen IJ, Valle-Onate R, Weber U, Wei J, Sieper J: The Assessment of SpondyloArthritis International Society classification criteria for peripheral spondyloarthritis and for spondyloarthritis in general. Ann Rheum Dis 2011, 70(1):25-31.

7. McGonagle D, Tan AL, Watad A, Helliwell P: Pathophysiology, assessment and treatment of psoriatic dactylitis. Nat Rev Rheumato/ 2019, 15(2):113-122.

8. Schett G, Lories RJ, D'Agostino MA, Elewaut D, Kirkham B, Soriano ER, McGonagle D: Enthesitis: from pathophysiology to treatment. Nat Rev Rheumatol 2017, 13(12):731-741.

9. Gossec L, Baraliakos X, Kerschbaumer A, de Wit M, Mclnnes I, Dougados M, Primdahl J, McGonagle DG, Aletaha D, Balanescu A, Balint PV, Bertheussen H, Boehncke WH, Burmester GR, Canete JD, Damjanov NS, Kragstrup TW, Kvien TK, Landewe RBM, Lories RJU, Marzo-Ortega H, Poddubnyy D, Rodrigues Manica SA, Schett G, Veale DJ, Van den Bosch FE, van der Heijde D, Smolen JS: EULAR recommendations for the management of psoriatic arthritis with pharmacological therapies: $\mathbf{2 0 1 9}$ update. Ann Rheum Dis 2020, 79(6):700-712.

10. Singh JA, Guyatt G, Ogdie A, Gladman DD, Deal C, Deodhar A, Dubreuil M, Dunham J, Husni ME, Kenny S, Kwan-Morley J, Lin J, Marchetta P, Mease PJ, Merola JF, Miner J, Ritchlin CT, Siaton B, Smith BJ, Van Voorhees AS, Jonsson AH, Shah AA, Sullivan N, Turgunbaev M, Coates LC, Gottlieb A, Magrey M, Nowell WB, Orbai AM, Reddy SM, Scher JU, Siegel E, Siegel M, Walsh JA, Turner AS, Reston J: Special Article: 2018 American College of Rheumatology/National Psoriasis Foundation Guideline for the Treatment of Psoriatic Arthritis. Arthritis Rheumatol 2019, 71(1):5-32.

11. Ward MM, Deodhar A, Gensler LS, Dubreuil M, Yu D, Khan MA, Haroon N, Borenstein D, Wang R, Biehl A, Fang MA, Louie G, Majithia V, Ng B, Bigham R, Pianin M, Shah AA, Sullivan N, Turgunbaev M, Oristaglio J, Turner A, Maksymowych WP, Caplan L: 2019 Update of the American College of Rheumatology/Spondylitis Association of America/Spondyloarthritis Research and Treatment Network Recommendations for the Treatment of Ankylosing Spondylitis and Nonradiographic Axial Spondyloarthritis. Arthritis Rheumatol 2019, 71(10):1599-1613.

12. Ogdie A, Coates LC, Gladman DD: Treatment guidelines in psoriatic arthritis. Rheumatology (Oxford) 2020, 59(Supplement_1):i37-i46.

13. Nakagomi D, Ikeda K, Okubo A, Iwamoto T, Sanayama Y, Takahashi K, Yamagata M, Takatori $H$, Suzuki K, Takabayashi K, Nakajima H: Ultrasound can improve the accuracy of the 2010 American College of Rheumatology/European League against rheumatism classification criteria for rheumatoid arthritis to predict the requirement for methotrexate treatment. Arthritis Rheum 2013, 65(4):890-898.

14. Kobayashi Y, Ikeda K, Nakamura T, Yamagata M, Nakazawa T, Tanaka S, Furuta S, Umibe T, Nakajima H: Severity and Diurnal Improvement of Morning Stiffness Independently Associate with Tenosynovitis in Patients with Rheumatoid Arthritis. PLoS One 2016, 11(11):e0166616. 
15. Bakewell CJ, Olivieri I, Aydin SZ, Dejaco C, Ikeda K, Gutierrez M, Terslev L, Thiele R, D'Agostino MA, Kaeley GS: Ultrasound and magnetic resonance imaging in the evaluation of psoriatic dactylitis: status and perspectives. J Rheumatol 2013, 40(12):1951-1957.

16. Brown AK, Conaghan PG, Karim Z, Quinn MA, Ikeda K, Peterfy CG, Hensor E, Wakefield RJ, O'Connor PJ, Emery P: An explanation for the apparent dissociation between clinical remission and continued structural deterioration in rheumatoid arthritis. Arthritis Rheum 2008, 58(10):2958-2967.

17. Saku A, Furuta S, Kato M, Furuya H, Suzuki K, Fukuta M, Suehiro K, Makita S, Tamachi T, Ikeda K, Takatori H, Maezawa Y, Suto A, Suzuki K, Hirose K, Nakajima H: Experience of musculoskeletal ultrasound scanning improves physicians' physical examination skills in assessment of synovitis. Clin Rheumatol 2020, 39(4):1091-1099.

18. Iwamoto T, Ikeda K, Hosokawa J, Yamagata M, Tanaka S, Norimoto A, Sanayama Y, Nakagomi D, Takahashi K, Hirose K, Sugiyama T, Sueishi M, Nakajima H: Prediction of relapse after discontinuation of biologic agents by ultrasonographic assessment in patients with rheumatoid arthritis in clinical remission: high predictive values of total gray-scale and power Doppler scores that represent residual synovial inflammation before discontinuation. Arthritis Care Res (Hoboken) 2014, 66(10):1576-1581.

19. Artis D, Spits H: The biology of innate lymphoid cells. Nature 2015, 517(7534):293-301.

20. Vivier E, Artis D, Colonna M, Diefenbach A, Di Santo JP, Eberl G, Koyasu S, Locksley RM, McKenzie ANJ, Mebius RE, Powrie F, Spits H: Innate Lymphoid Cells: 10 Years On. Cell 2018, 174(5):1054-1066.

21. Rosser EC, Lom H, Bending D, Duurland CL, Bajaj-Elliott M, Wedderburn LR: Innate Lymphoid Cells and T Cells Contribute to the Interleukin-17A Signature Detected in the Synovial Fluid of Patients With Juvenile Idiopathic Arthritis. Arthritis Rheumatol 2019, 71(3):460-467.

22. Rodriguez-Carrio J, Hahnlein JS, Ramwadhdoebe TH, Semmelink JF, Choi IY, van Lienden KP, Maas M, Gerlag DM, Tak PP, Geijtenbeek TB, van Baarsen LG: Brief Report: Altered Innate Lymphoid Cell Subsets in Human Lymph Node Biopsy Specimens Obtained During the At-Risk and Earliest Phases of Rheumatoid Arthritis. Arthritis Rheumato/2017, 69(1):70-76.

23. Rauber S, Luber M, Weber S, Maul L, Soare A, Wohlfahrt T, Lin NY, Dietel K, Bozec A, Herrmann M, Kaplan MH, Weigmann B, Zaiss MM, Fearon U, Veale DJ, Canete JD, Distler O, Rivellese F, Pitzalis C, Neurath MF, McKenzie ANJ, Wirtz S, Schett G, Distler JHW, Ramming A: Resolution of inflammation by interleukin-9-producing type 2 innate lymphoid cells. Nat Med 2017, 23(8):938-944.

24. Ciccia F, Guggino G, Rizzo A, Saieva L, Peralta S, Giardina A, Cannizzaro A, Sireci G, De Leo G, Alessandro R, Triolo G: Type 3 innate lymphoid cells producing IL-17 and IL-22 are expanded in the gut, in the peripheral blood, synovial fluid and bone marrow of patients with ankylosing spondylitis. Ann Rheum Dis 2015, 74(9):1739-1747.

25. Leijten EF, van Kempen TS, Boes M, Michels-van Amelsfort JM, Hijnen D, Hartgring SA, van Roon JA, Wenink MH, Radstake TR: Brief report: enrichment of activated group 3 innate lymphoid cells in psoriatic arthritis synovial fluid. Arthritis Rheumato/ 2015, 67(10):2673-2678. 
26. Blijdorp ICJ, Menegatti S, van Mens LJJ, van de Sande MGH, Chen S, Hreggvidsdottir HS, Noordenbos T, Latuhihin TE, Bernink JH, Spits H, Rogge L, Baeten DLP, Yeremenko NG: Expansion of Interleukin-22- and Granulocyte-Macrophage Colony-Stimulating Factor-Expressing, but Not Interleukin-17A-Expressing, Group 3 Innate Lymphoid Cells in the Inflamed Joints of Patients With Spondyloarthritis. Arthritis Rheumatol 2019, 71(3):392-402.

27. Soare A, Weber S, Maul L, Rauber S, Gheorghiu AM, Luber M, Houssni I, Kleyer A, von Pickardt G, Gado M, Simon D, Rech J, Schett G, Distler JHW, Ramming A: Cutting Edge: Homeostasis of Innate Lymphoid Cells Is Imbalanced in Psoriatic Arthritis. J Immuno/ 2018, 200(4):1249-1254.

28. Al-Mossawi MH, Chen L, Fang H, Ridley A, de Wit J, Yager N, Hammitzsch A, Pulyakhina I, Fairfax BP, Simone D, Yi Y, Bandyopadhyay S, Doig K, Gundle R, Kendrick B, Powrie F, Knight JC, Bowness P: Unique transcriptome signatures and GM-CSF expression in lymphocytes from patients with spondyloarthritis. Nat Commun 2017, 8(1):1510.

29. Cuthbert RJ, Fragkakis EM, Dunsmuir R, Li Z, Coles M, Marzo-Ortega H, Giannoudis PV, Jones E, ElSherbiny YM, McGonagle D: Brief Report: Group 3 Innate Lymphoid Cells in Human Enthesis. Arthritis Rheumatol 2017, 69(9):1816-1822.

30. Altobelli E, Angeletti PM, Piccolo D, De Angelis R: Synovial Fluid and Serum Concentrations of Inflammatory Markers in Rheumatoid Arthritis, Psoriatic Arthritis and Osteoarthitis: A Systematic Review. Curr Rheumatol Rev 2017, 13(3):170-179.

31. Felson DT, Anderson JJ, Boers M, Bombardier C, Chernoff M, Fried B, Furst D, Goldsmith C, Kieszak S, Lightfoot $\mathrm{R}$, et al.: The American College of Rheumatology preliminary core set of disease activity measures for rheumatoid arthritis clinical trials. The Committee on Outcome Measures in Rheumatoid Arthritis Clinical Trials. Arthritis Rheum 1993, 36(6):729-740.

32. Maksymowych WP, Mallon C, Morrow S, Shojania K, Olszynski WP, Wong RL, Sampalis J, ConnerSpady B: Development and validation of the Spondyloarthritis Research Consortium of Canada (SPARCC) Enthesitis Index. Ann Rheum Dis 2009, 68(6):948-953.

33. D'Agostino MA, Terslev L, Aegerter P, Backhaus M, Balint P, Bruyn GA, Filippucci E, Grassi W, lagnocco A, Jousse-Joulin S, Kane D, Naredo E, Schmidt W, Szkudlarek M, Conaghan PG, Wakefield RJ: Scoring ultrasound synovitis in rheumatoid arthritis: a EULAR-OMERACT ultrasound taskforce-Part 1: definition and development of a standardised, consensus-based scoring system. RMD Open 2017, 3(1):e000428.

34. Naredo E, D'Agostino MA, Wakefield RJ, Moller I, Balint PV, Filippucci E, lagnocco A, Karim Z, Terslev L, Bong DA, Garrido J, Martinez-Hernandez D, Bruyn GA: Reliability of a consensus-based ultrasound score for tenosynovitis in rheumatoid arthritis. Ann Rheum Dis 2013, 72(8):1328-1334.

35. Tan AL, Fukuba E, Halliday NA, Tanner SF, Emery P, McGonagle D: High-resolution MRI assessment of dactylitis in psoriatic arthritis shows flexor tendon pulley and sheath-related enthesitis. Ann Rheum Dis 2015, 74(1):185-189.

36. Roan F, Stoklasek TA, Whalen E, Molitor JA, Bluestone JA, Buckner JH, Ziegler SF: CD4+ Group 1 Innate Lymphoid Cells (ILC) Form a Functionally Distinct ILC Subset That Is Increased in Systemic 
Sclerosis. J Immunol 2016, 196(5):2051-2062.

37. Sokolova MV, Simon D, Nas K, Zaiss MM, Luo Y, Zhao Y, Rech J, Schett G: A set of serum markers detecting systemic inflammation in psoriatic skin, entheseal, and joint disease in the absence of Creactive protein and its link to clinical disease manifestations. Arthritis Res Ther 2020, 22(1):26.

38. Kolbinger F, Loesche $C$, Valentin MA, Jiang X, Cheng Y, Jarvis P, Peters T, Calonder C, Bruin G, Polus F, Aigner B, Lee DM, Bodenlenz M, Sinner F, Pieber TR, Patel DD: beta-Defensin 2 is a responsive biomarker of IL-17A-driven skin pathology in patients with psoriasis. J Allergy Clin Immunol 2017, 139(3):923-932 e928.

39. Felson DT, Anderson JJ, Boers M, Bombardier C, Furst D, Goldsmith C, Katz LM, Lightfoot R, Jr., Paulus $\mathrm{H}$, Strand $\mathrm{V}$, et al.: American College of Rheumatology. Preliminary definition of improvement in rheumatoid arthritis. Arthritis Rheum 1995, 38(6):727-735.

40. Breiman L: Random Forests. Mach Learn 2001, 45:5-32.

41. Shi T, Horvath S: Unsupervised learning with random forest predictors. J Comput Graph Stat 2006, 15:113-138.

42. Mclnnes L, Healy J, Melville J: Uniform Manifold Approximation and Projection for Dimension Reduction. ArXiv 2018:1802.03426.

43. Kaufman L, Rousseeuw PJ: Clustering by means of medoids. In: Statistical Data Analysis based on the L1 Norm. Edited by Dodge Y. North-Holland, Amsterdam; 1987: 405-416.

44. Gutierrez M, Filippucci E, Salaffi F, Di Geso L, Grassi W: Differential diagnosis between rheumatoid arthritis and psoriatic arthritis: the value of ultrasound findings at metacarpophalangeal joints level. Ann Rheum Dis 2011, 70(6):1111-1114.

45. Mauro D, Macaluso F, Fasano S, Alessandro R, Ciccia F: ILC3 in Axial Spondyloarthritis: the Gut Angle. Curr Rheumatol Rep 2019, 21(7):37.

46. Kunwar S, Dahal K, Sharma S: Anti-IL-17 therapy in treatment of rheumatoid arthritis: a systematic literature review and meta-analysis of randomized controlled trials. Rheumatol Int 2016, 36(8):10651075.

47. Smolen JS, Agarwal SK, llivanova E, Xu XL, Miao Y, Zhuang Y, Nnane I, Radziszewski W, Greenspan A, Beutler A, Baker D: A randomised phase II study evaluating the efficacy and safety of subcutaneously administered ustekinumab and guselkumab in patients with active rheumatoid arthritis despite treatment with methotrexate. Ann Rheum Dis 2017, 76(5):831-839.

48. Jansen PA, Rodijk-Olthuis D, Hollox EJ, Kamsteeg M, Tjabringa GS, de Jongh GJ, van VlijmenWillems IM, Bergboer JG, van Rossum MM, de Jong EM, den Heijer M, Evers AW, Bergers M, Armour $\mathrm{JA}$, Zeeuwen PL, Schalkwijk J: Beta-defensin-2 protein is a serum biomarker for disease activity in psoriasis and reaches biologically relevant concentrations in lesional skin. PLoS One 2009, 4(3):e4725.

49. Kingsley GH, Kowalczyk A, Taylor H, Ibrahim F, Packham JC, McHugh NJ, Mulherin DM, Kitas GD, Chakravarty K, Tom BD, O'Keeffe AG, Maddison PJ, Scott DL: A randomized placebo-controlled trial of methotrexate in psoriatic arthritis. Rheumatology (Oxford) 2012, 51(8):1368-1377. 
50. Mease PJ, Gladman DD, Collier DH, Ritchlin CT, Helliwell PS, Liu L, Kricorian G, Chung JB: Etanercept and Methotrexate as Monotherapy or in Combination for Psoriatic Arthritis: Primary Results From a Randomized, Controlled Phase III Trial. Arthritis Rheumatol 2019, 71(7):1112-1124.

\section{Figures}

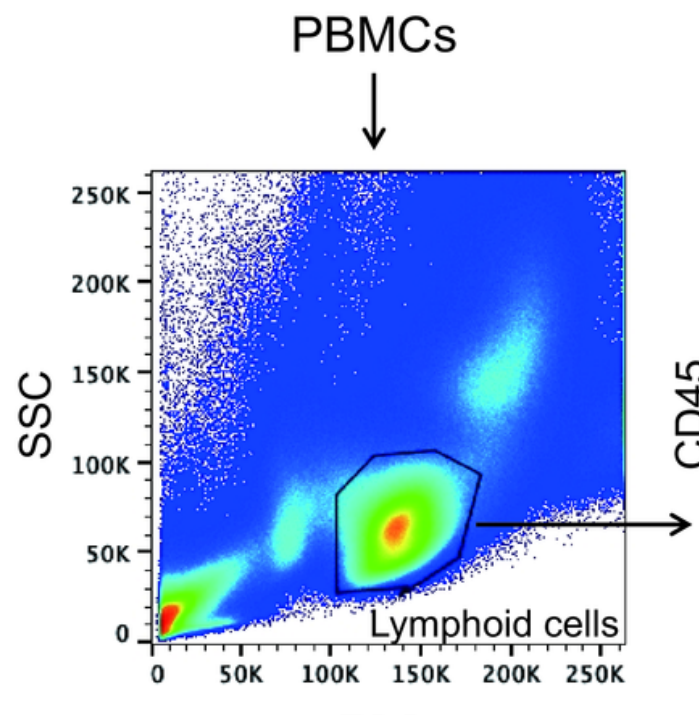

FSC

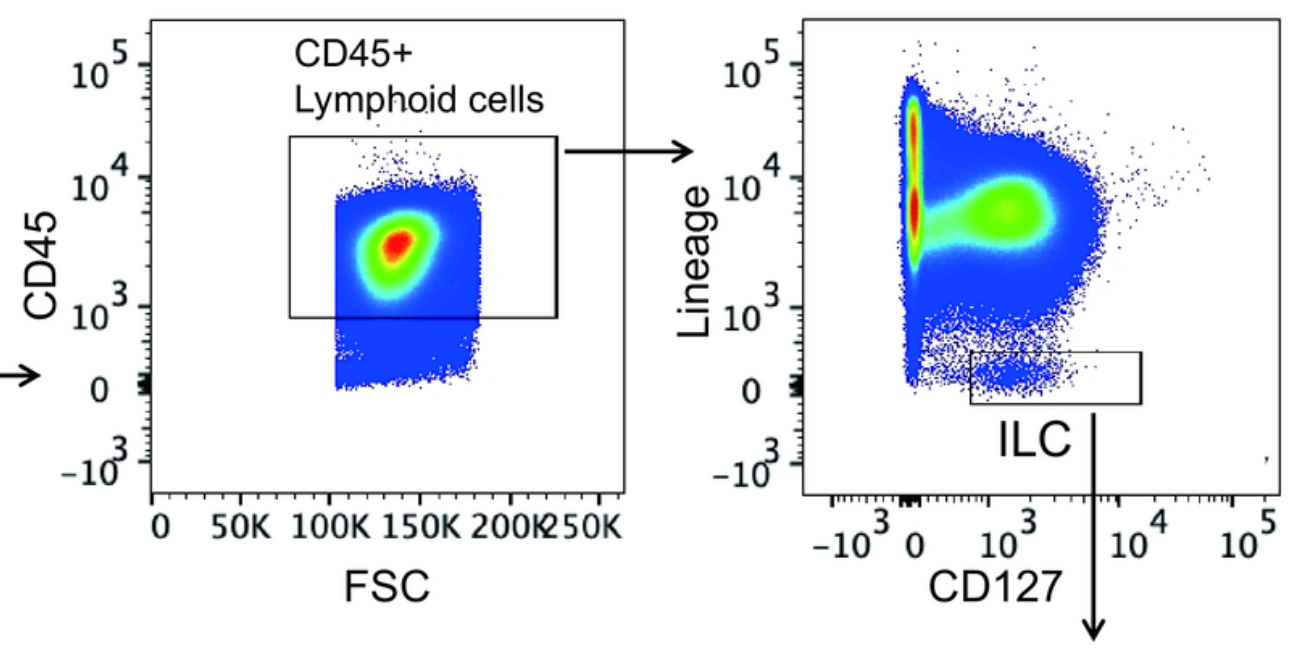

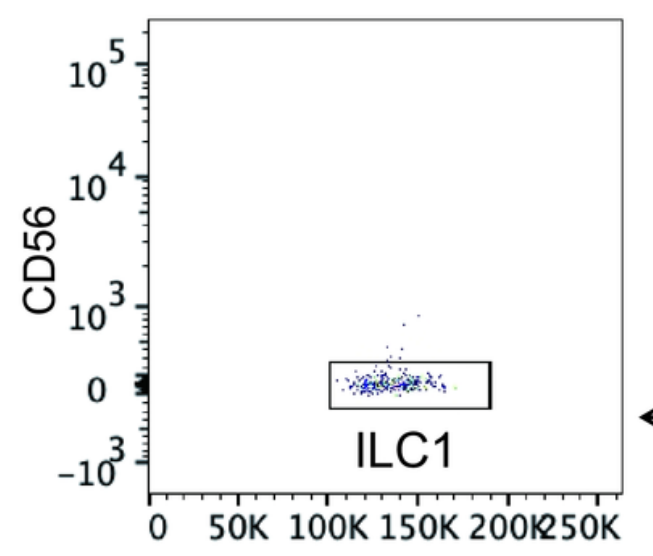

FSC

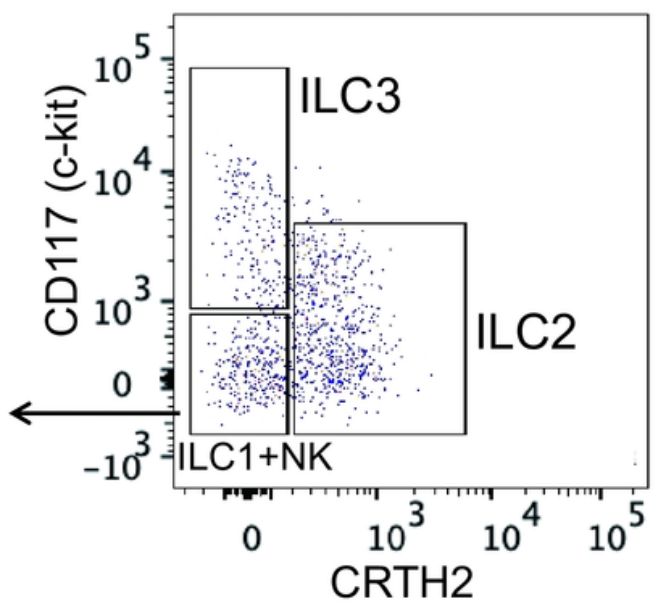

\section{Figure 1}

Gating method to identify innate lymphoid cells by flowcytometry After live lymphoid cells, singlets, and CD45+cells were gated, innate lymphoid cells (ILCs) were identified as lineage markers- CD127+ cells. Lineage markers included CD3, CD14, CD19, CD11c, FceRla, CD94, CD123, CD34, and CD16. Group 1-3 ILCs (ILC1-3) were defined as CRTH2- c-kit- CD56- cells, CRTH2+ cells, and CRTH2- c-kit+ cells, respectively. SC: forward scatter; SSC: side scatter 


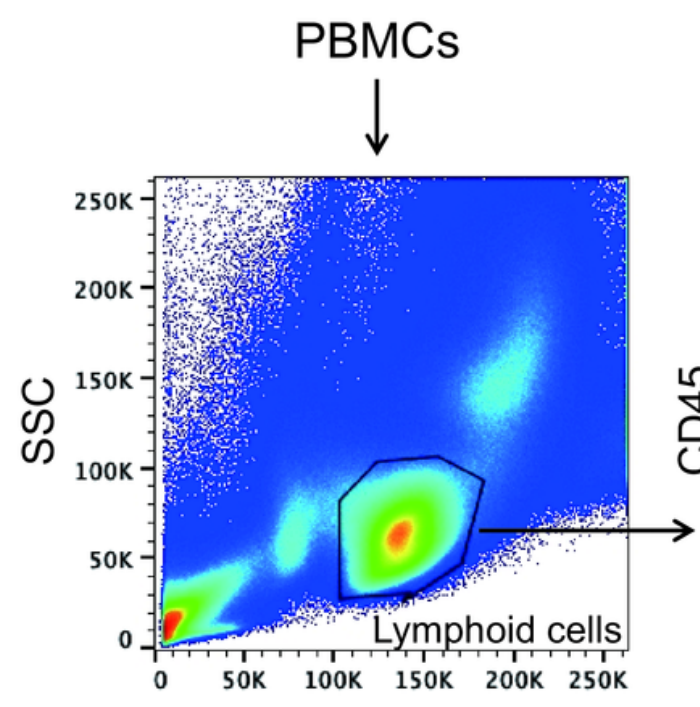

FSC
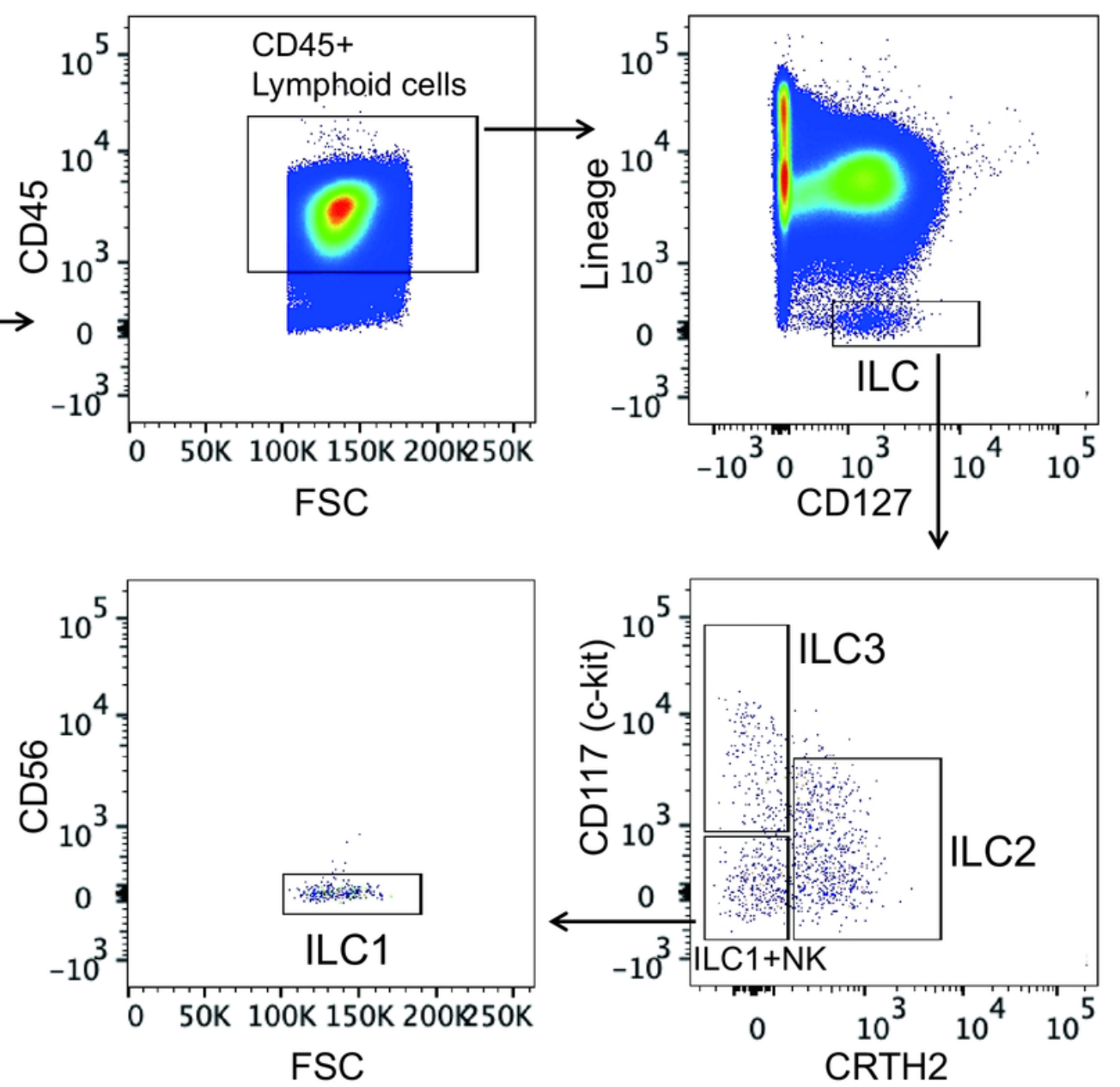

\section{Figure 1}

Gating method to identify innate lymphoid cells by flowcytometry After live lymphoid cells, singlets, and CD45+cells were gated, innate lymphoid cells (ILCs) were identified as lineage markers- CD127+ cells. Lineage markers included CD3, CD14, CD19, CD11c, FceRla, CD94, CD123, CD34, and CD16. Group 1-3 ILCs (ILC1-3) were defined as CRTH2- c-kit- CD56- cells, CRTH2+ cells, and CRTH2- c-kit+ cells, respectively. SC: forward scatter; SSC: side scatter 


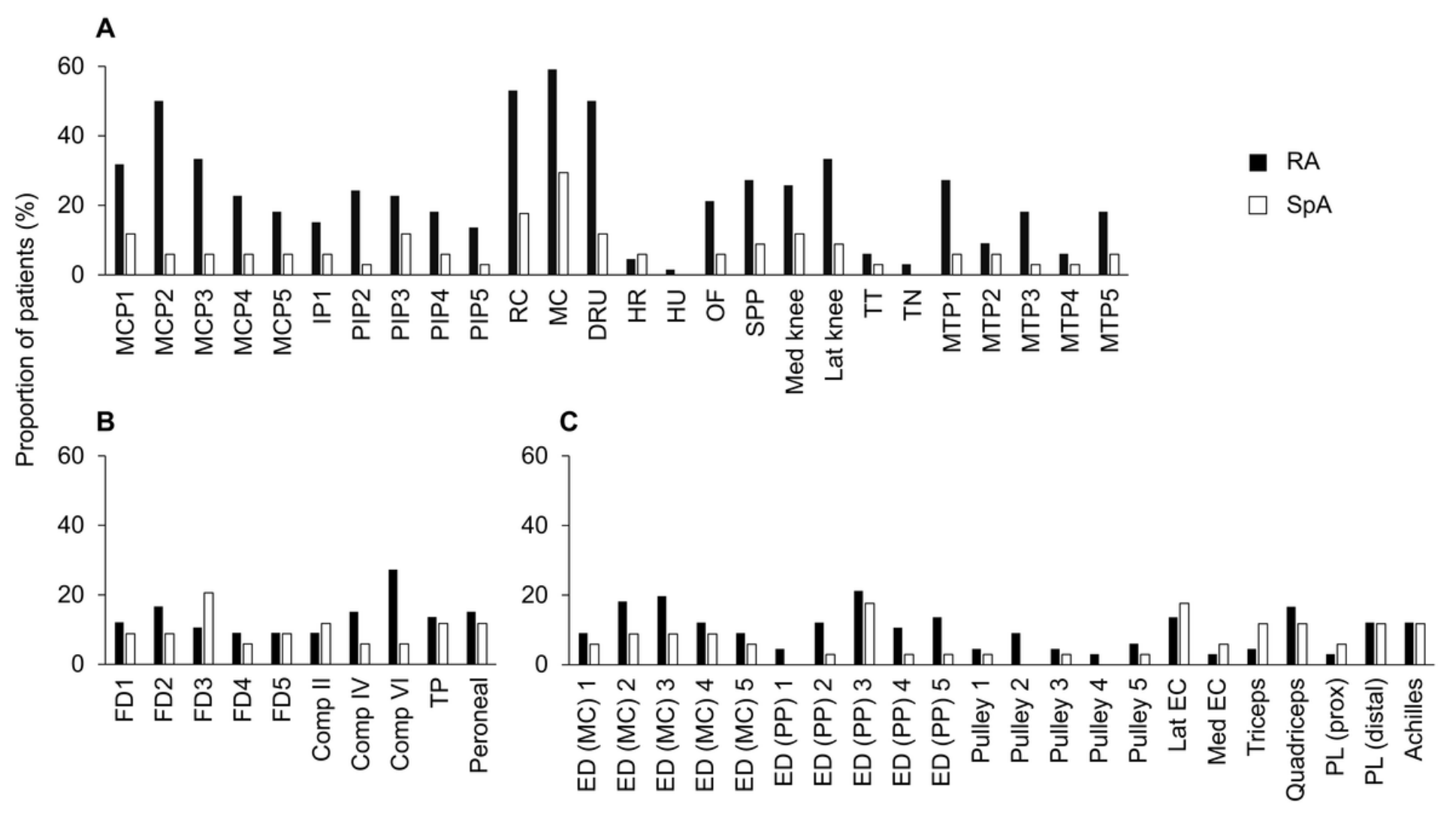

Figure 2

Proportions of patients with positive power Doppler score for each site scanned A. Joints evaluated for synovitis. B. Tendons evaluated for tenosynovitis. C. Entheses evaluated for enthesitis. RA: rheumatoid arthritis; SpA: spondyloarthritis; MCP: metacarpophalangeal; IP: interphalangeal; PIP: proximal interphalangeal; RC: radiocarpal; MC: midcarpal; DRU: distal radioulnar; HR: humeroradial; HU: humeroulnar; OF: olecranon fossa; SPP: suprapatellar pouch; Med knee: medial aspect of knee; Lat knee: lateral aspect of knee; TT: tibiotalar; TN: talonavicular; MTP: metatarsophalangeal; FD: flexor digitorum; Comp: compartment of wrist extensor tendon; TP: tibialis posterior; ED (MC): extensor digitorum at metacarpal head; ED (PP): extensor digitorum insertion into proximal phalanx; Lat EC: lateral epicondyle; Med EC: medial epicondyle; PL (prox): proximal attachment of patellar ligament; PL (distal): distal attachment of patellar ligament 


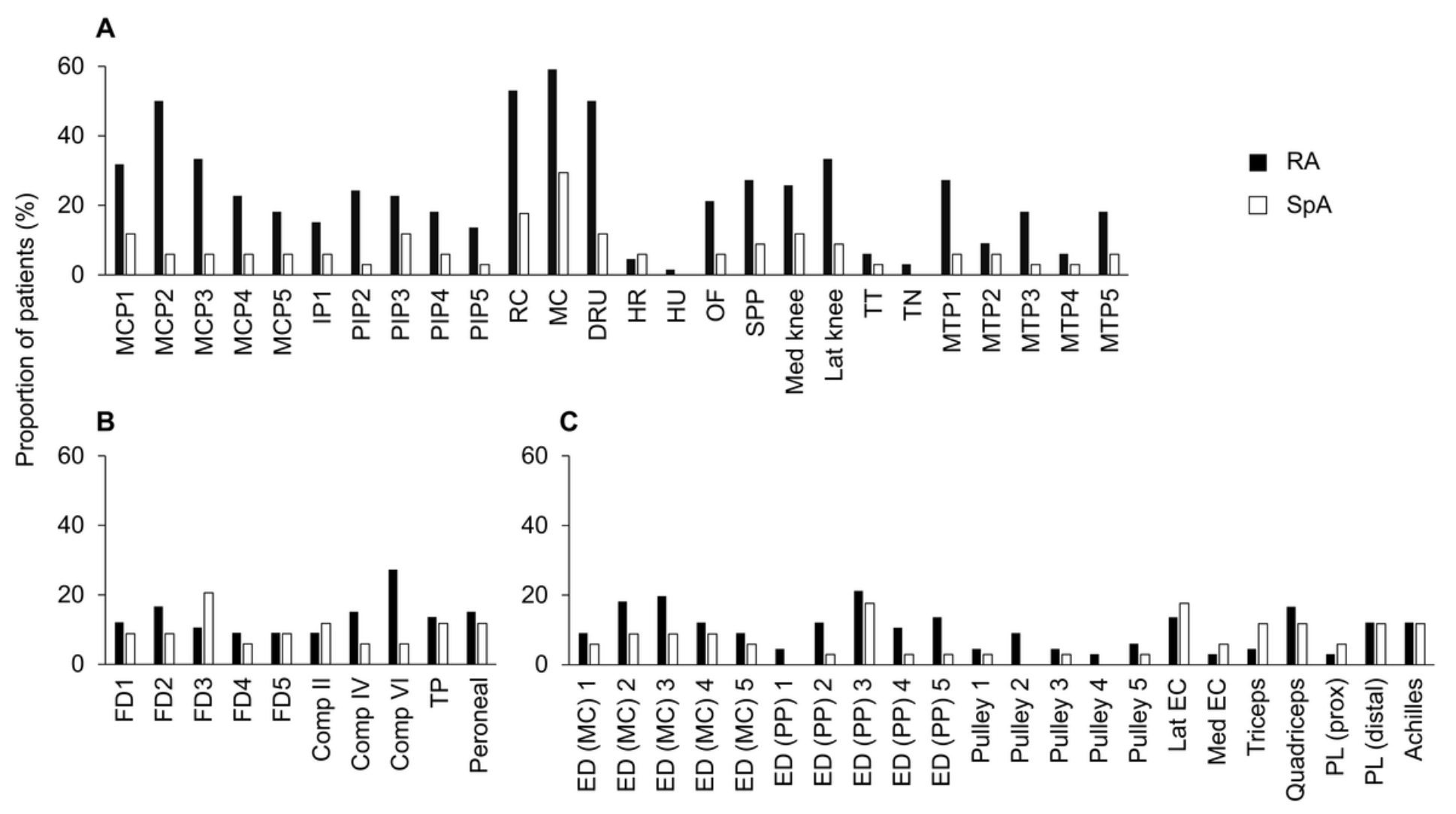

Figure 2

Proportions of patients with positive power Doppler score for each site scanned A. Joints evaluated for synovitis. B. Tendons evaluated for tenosynovitis. C. Entheses evaluated for enthesitis. RA: rheumatoid arthritis; SpA: spondyloarthritis; MCP: metacarpophalangeal; IP: interphalangeal; PIP: proximal interphalangeal; RC: radiocarpal; MC: midcarpal; DRU: distal radioulnar; HR: humeroradial; HU: humeroulnar; OF: olecranon fossa; SPP: suprapatellar pouch; Med knee: medial aspect of knee; Lat knee: lateral aspect of knee; TT: tibiotalar; TN: talonavicular; MTP: metatarsophalangeal; FD: flexor digitorum; Comp: compartment of wrist extensor tendon; TP: tibialis posterior; ED (MC): extensor digitorum at metacarpal head; ED (PP): extensor digitorum insertion into proximal phalanx; Lat EC: lateral epicondyle; Med EC: medial epicondyle; PL (prox): proximal attachment of patellar ligament; PL (distal): distal attachment of patellar ligament 

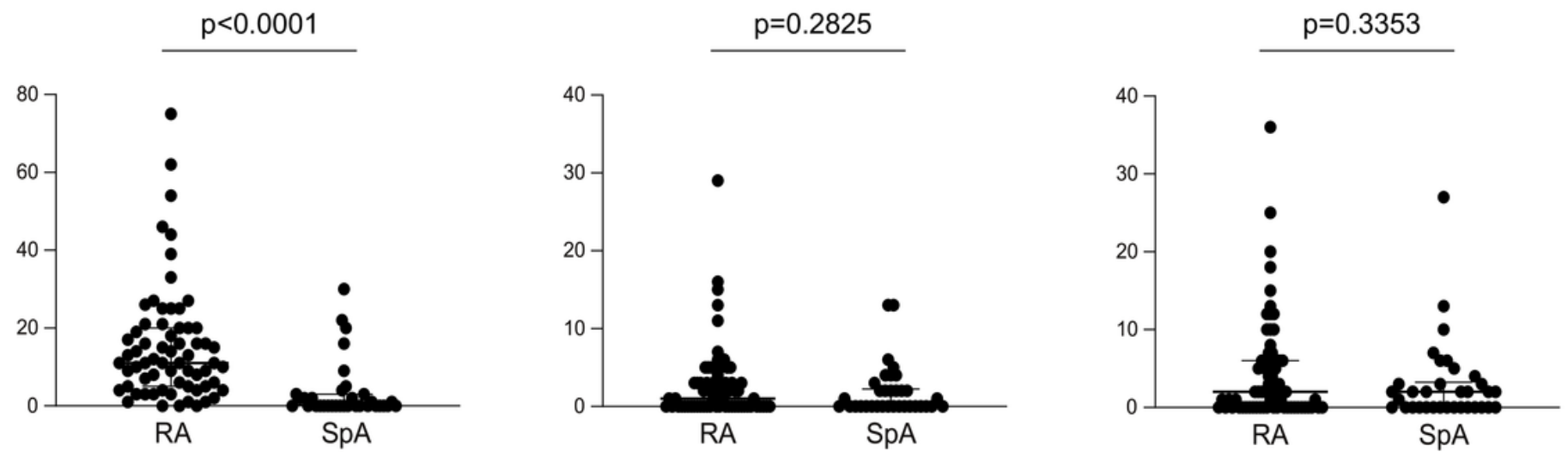

Figure 3

Differences in total ultrasound scores between rheumatoid arthritis and spondyloarthritis Total synovitis/tenosynovitis/enthesitis scores are compared between patients with rheumatoid arthritis (RA) and those with spondyloarthritis (SpA).

Total synovitis score

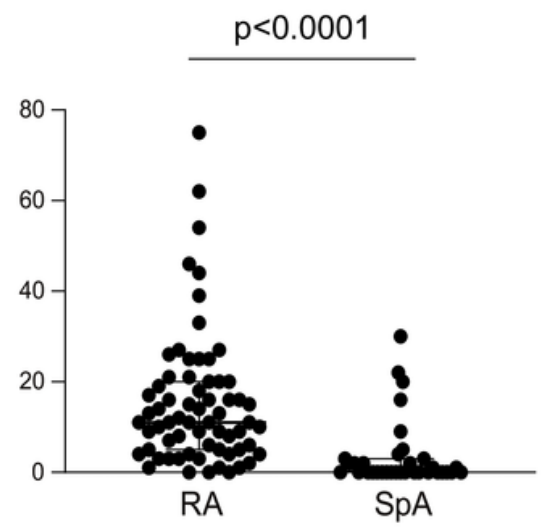

Total tenosynovitis score

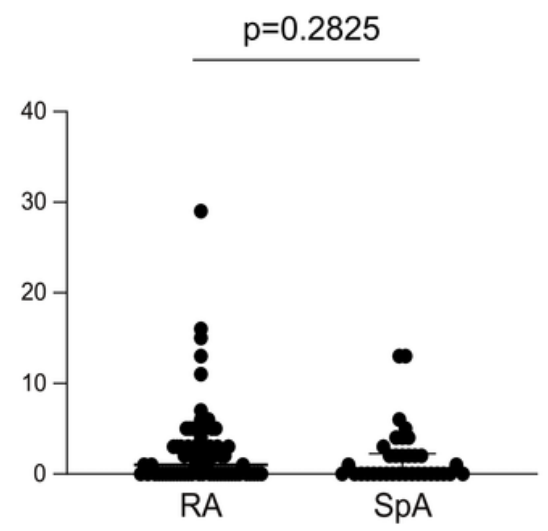

Total enthesitis score

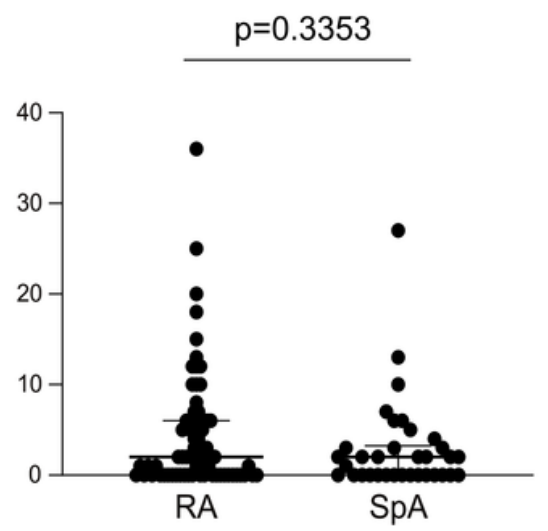

\section{Figure 3}

Differences in total ultrasound scores between rheumatoid arthritis and spondyloarthritis Total synovitis/tenosynovitis/enthesitis scores are compared between patients with rheumatoid arthritis (RA) and those with spondyloarthritis (SpA). 

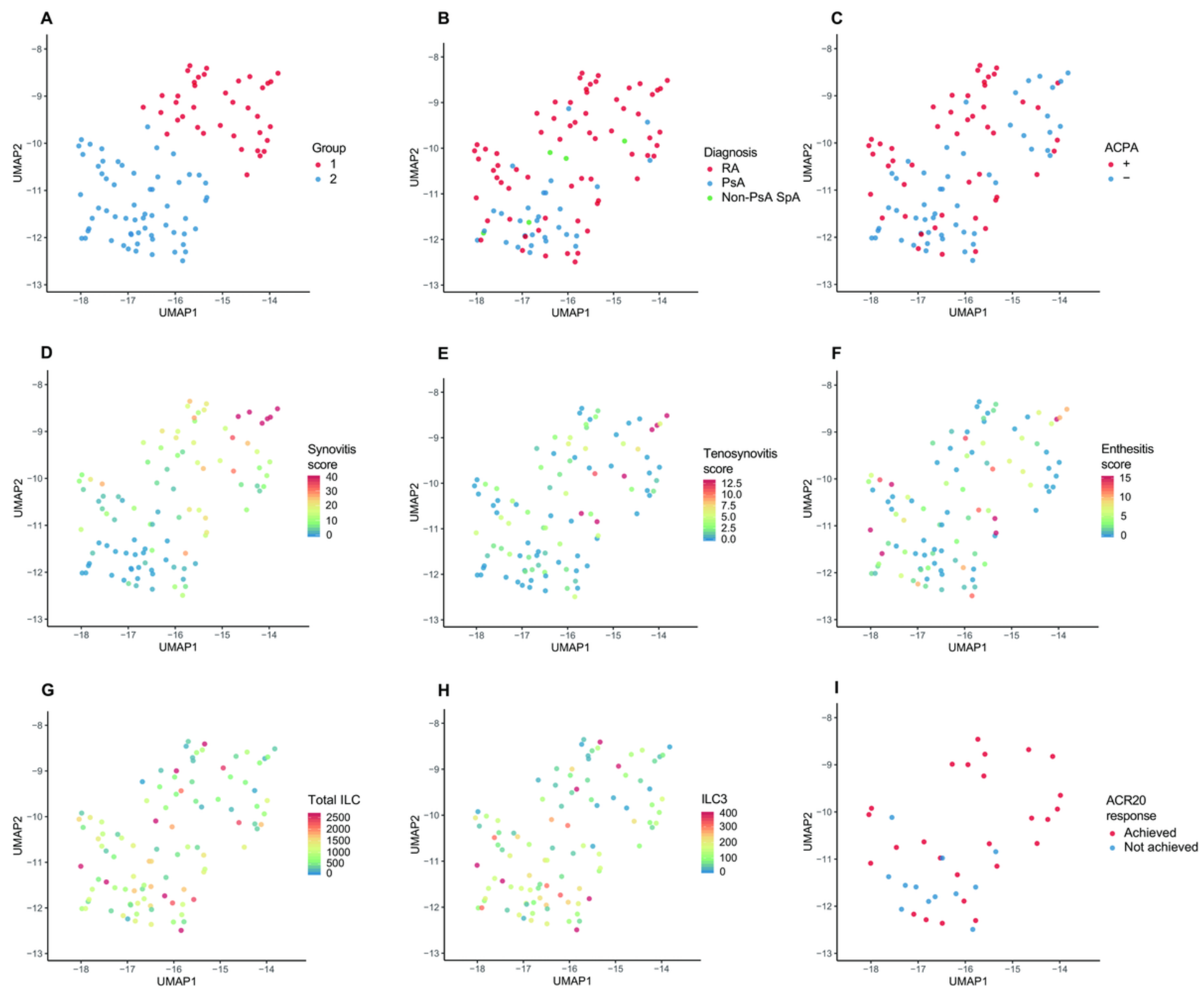

Figure 4

Clustering of patients based on ultrasound assessment Positional relationship among patients $(n=100)$ based on power Doppler scores (116 sites) is plotted by Uniform Manifold Approximation and Projection (UMAP). A. Partitioning Around Medoids (PAM) clustering of patients based on the two scaling coordinates of UMAP. B-I. Parameters are mapped on the UMAP plot: B. clinical diagnoses (rheumatoid arthritis [RA], psoriatic arthritis [PsA], non-PsA spondyloarthritis [SpA]), C. anti-citrullinated protein antibody (ACPA) positivity, D. total synovitis score, E. total tenosynovitis score, F. total enthesitis score, G. peripheral count of total innate lymphoid cell (ILC), H. peripheral ILC3 count, I. ACR20 response to methotrexate (MTX). 

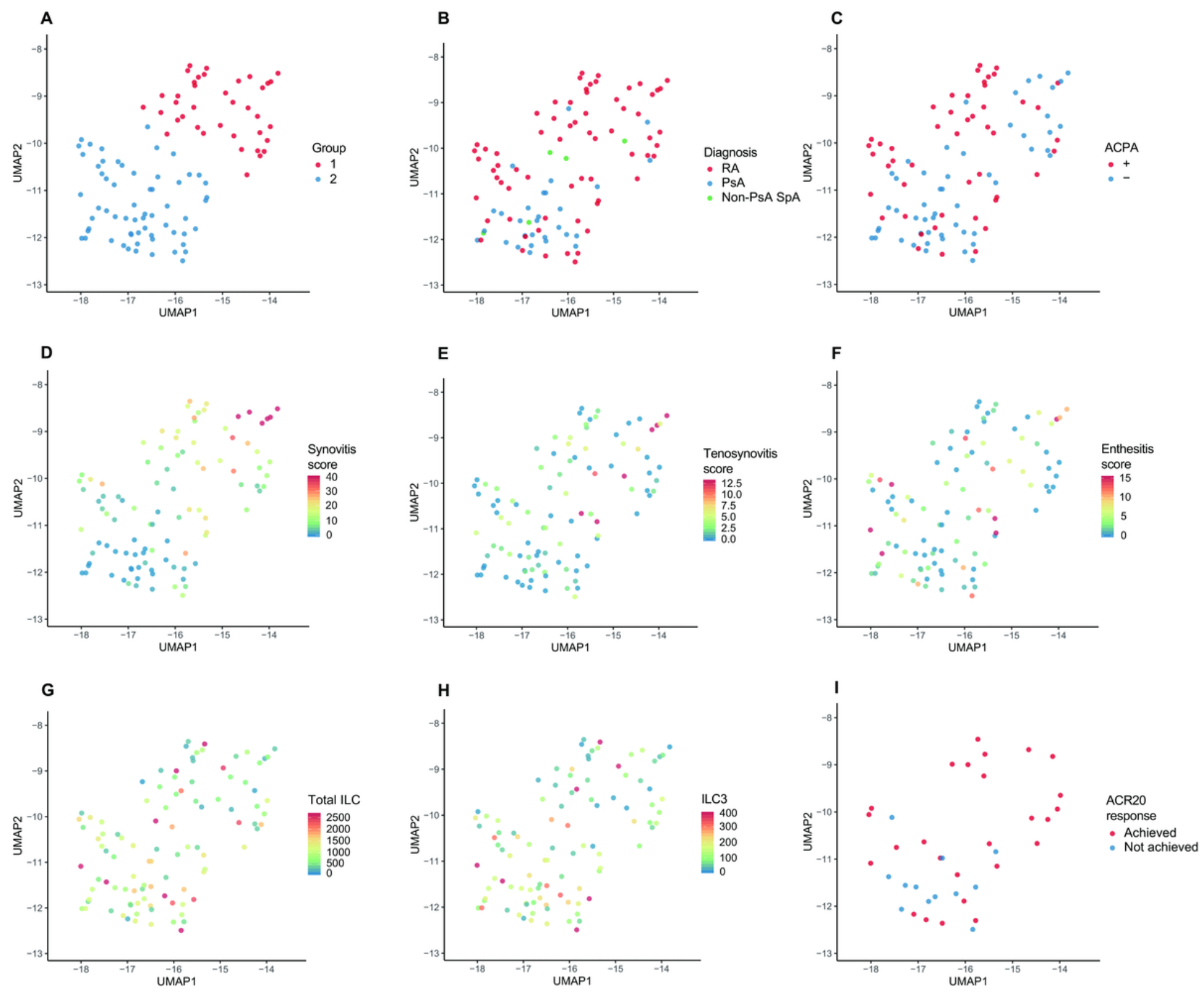

Figure 4

Clustering of patients based on ultrasound assessment Positional relationship among patients $(n=100)$ based on power Doppler scores (116 sites) is plotted by Uniform Manifold Approximation and Projection (UMAP). A. Partitioning Around Medoids (PAM) clustering of patients based on the two scaling coordinates of UMAP. B-I. Parameters are mapped on the UMAP plot: B. clinical diagnoses (rheumatoid arthritis [RA], psoriatic arthritis [PsA], non-PsA spondyloarthritis [SpA]), C. anti-citrullinated protein antibody (ACPA) positivity, D. total synovitis score, E. total tenosynovitis score, F. total enthesitis score, G. peripheral count of total innate lymphoid cell (ILC), H. peripheral ILC3 count, I. ACR20 response to methotrexate (MTX). 
A
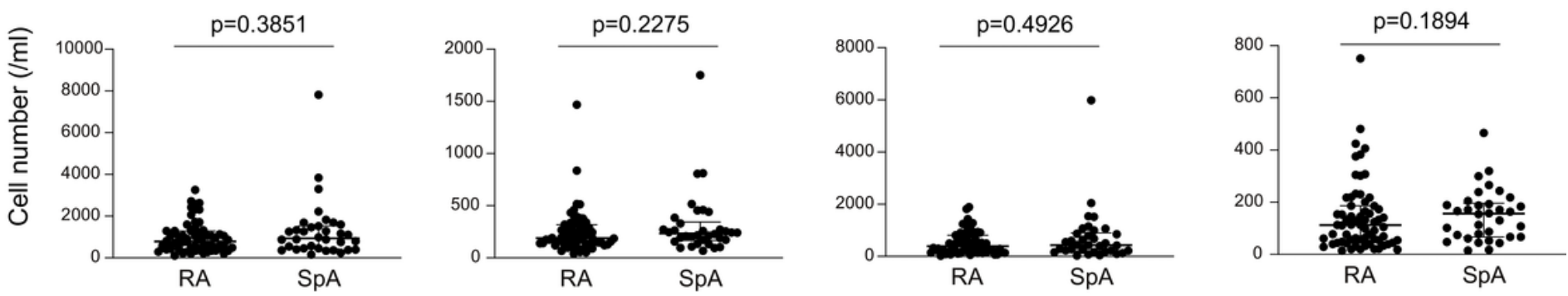

B

Total ILC

ILC1

ILC2

ILC3
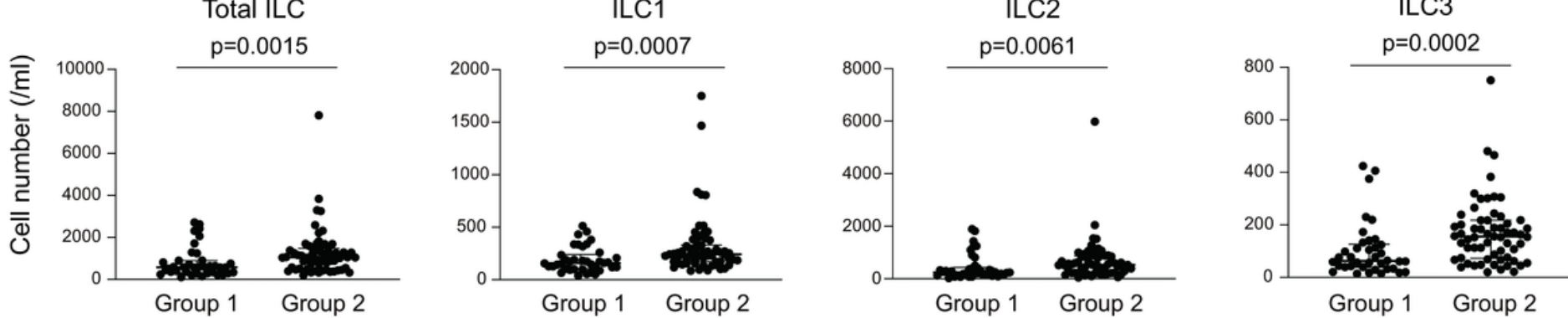

Figure 5

Differences in innate lymphoid cell numbers between groups Numbers of total innate lymphoid cell (ILC) and Group 1-3 ILCs (ILC1, ILC2, and ILC3) in the peripheral blood are compared A. between patients with RA and those with SpA and B. between Group 1 (synovitis-dominant pattern) and Group 2 (synovitisnondominant pattern).

A

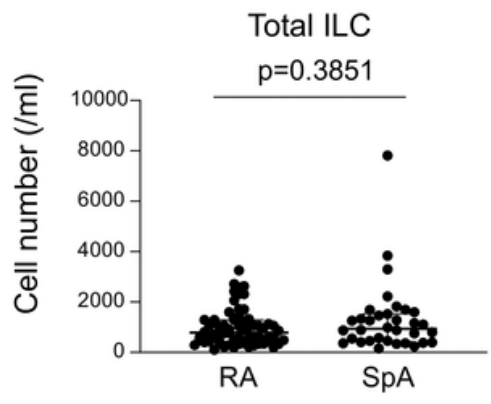

B

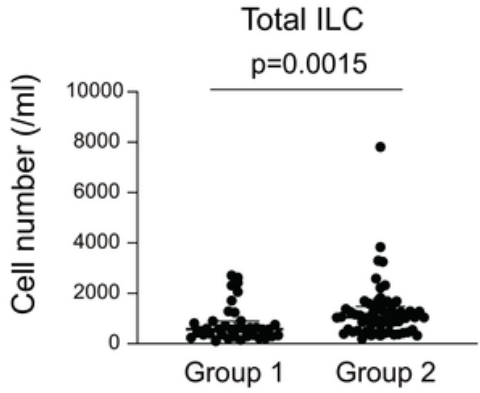

ILC1

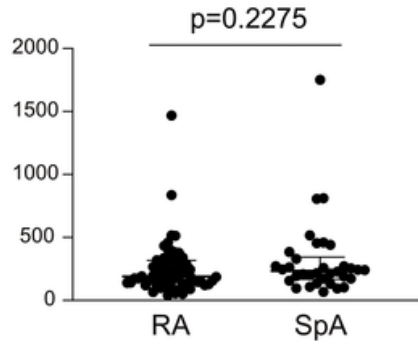

ILC1

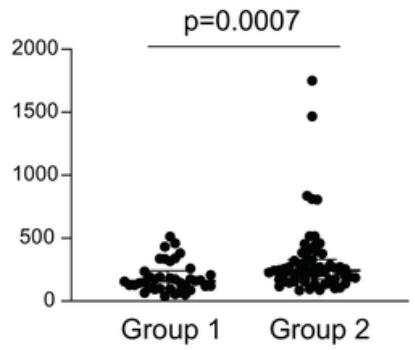

ILC2

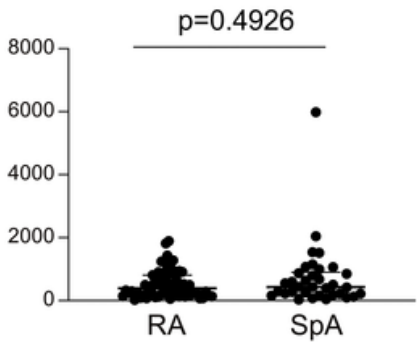

ILC2

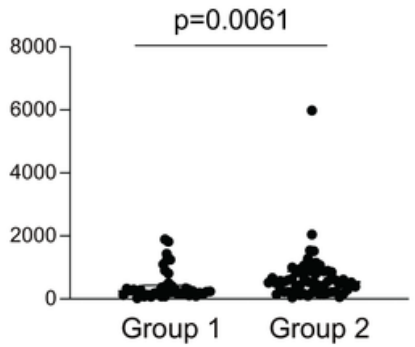

ILC3

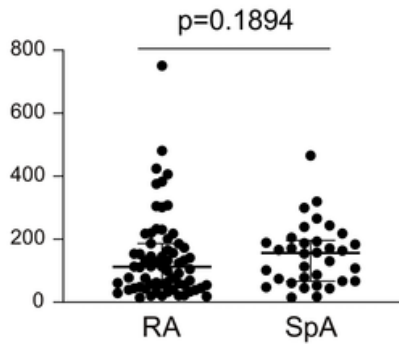

ILC3

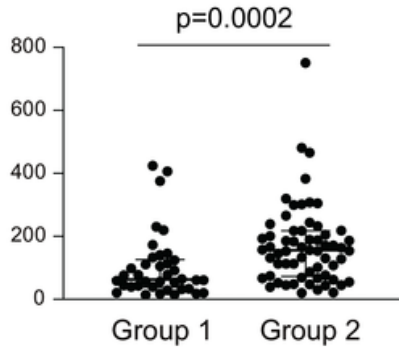

Figure 5

Differences in innate lymphoid cell numbers between groups Numbers of total innate lymphoid cell (ILC) and Group 1-3 ILCs (ILC1, ILC2, and ILC3) in the peripheral blood are compared A. between patients with RA and those with SpA and B. between Group 1 (synovitis-dominant pattern) and Group 2 (synovitisnondominant pattern). 
A
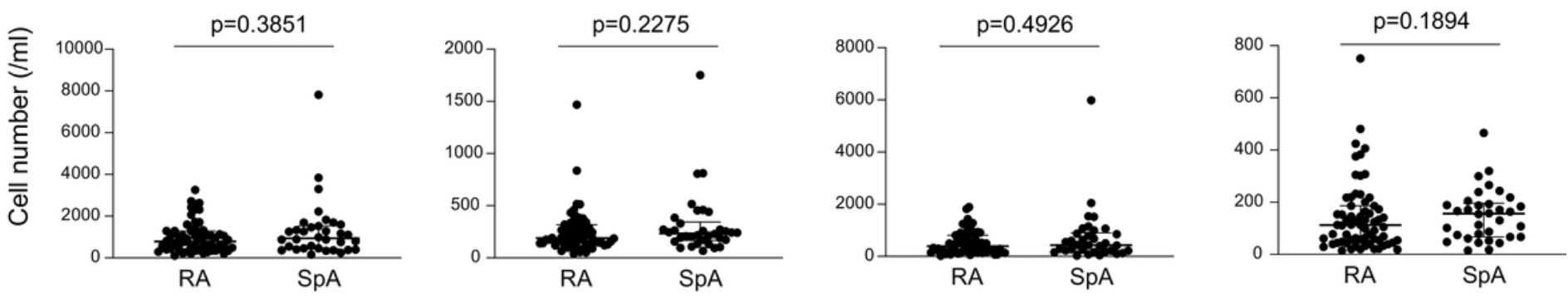

B

Total ILC

ILC1

ILC2

ILC3
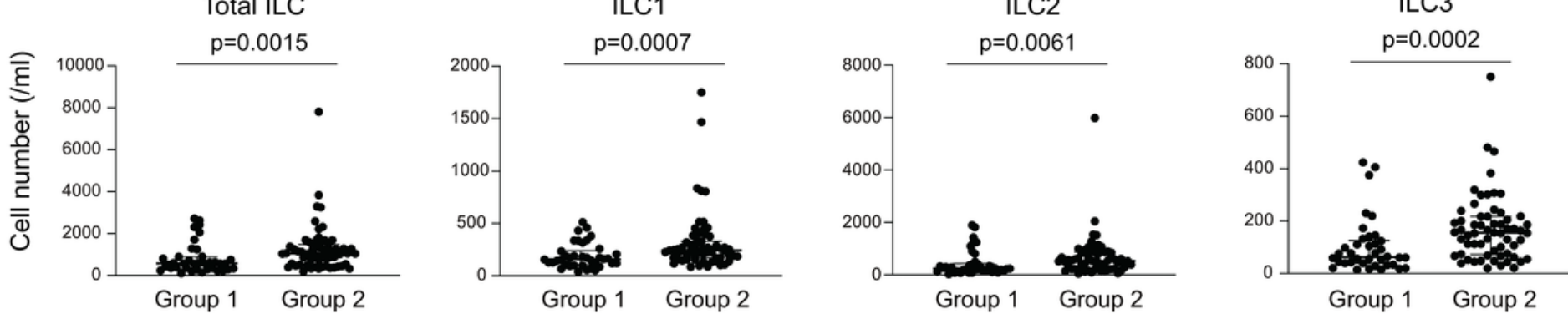

Figure 6

Clustering of patients based on serum cytokine/chemokines Shown are a heatmap representing the serum levels of 20 biomarkers and dendrograms illustrating hierarchical clustering of these cytokine/chemokines and patients $(n=99)$. The clinical diagnosis (rheumatoid arthritis vs. spondyloarthritis) and the ultrasound-based inflammation pattern (Group 1 vs. Group 2) are provided below the heatmap.

A

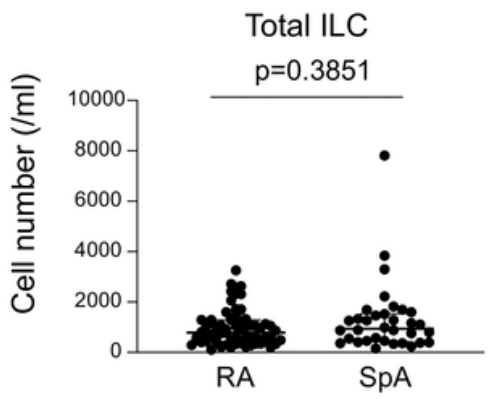

B

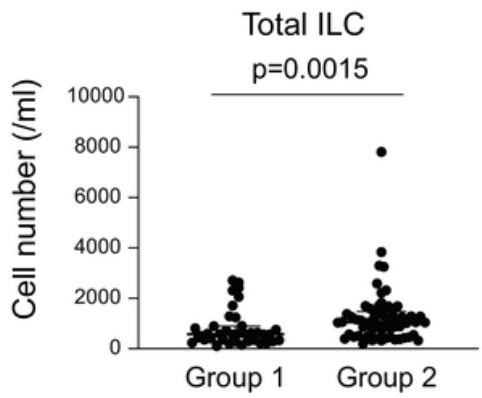

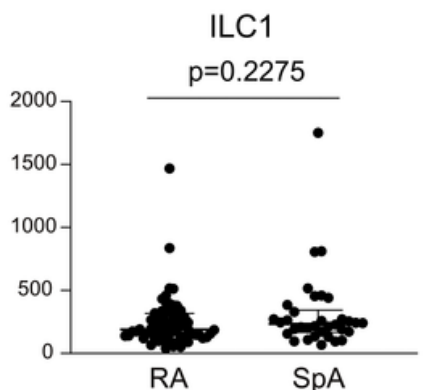

ILC1

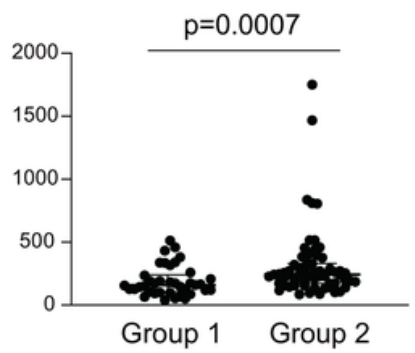

ILC2

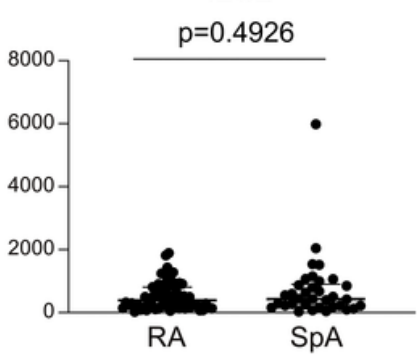

ILC2

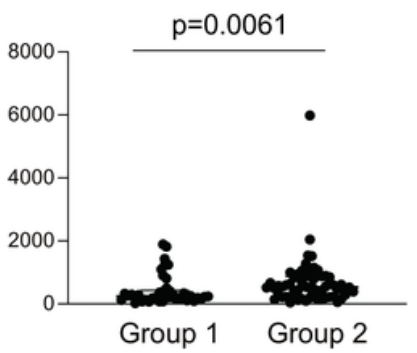

LC3

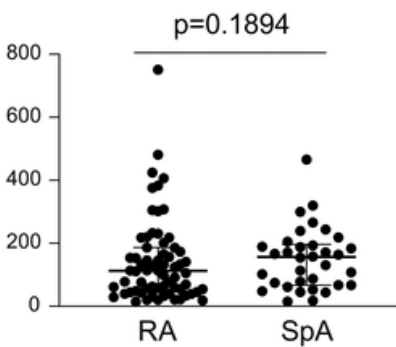

ILC3

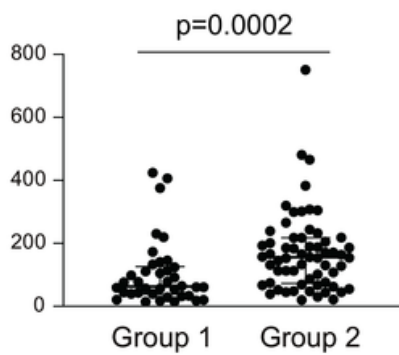

Figure 6

Clustering of patients based on serum cytokine/chemokines Shown are a heatmap representing the serum levels of 20 biomarkers and dendrograms illustrating hierarchical clustering of these cytokine/chemokines and patients $(n=99)$. The clinical diagnosis (rheumatoid arthritis vs. 
spondyloarthritis) and the ultrasound-based inflammation pattern (Group 1 vs. Group 2) are provided below the heatmap. 